\title{
Influence of Various Soluble Carbonates on the Hydration of Portland Cement studied by X-ray Diffraction
}

\author{
Simona Medvešček, ${ }^{1}$ Venčeslav Kaučič ${ }^{2}$ and Anton Meden ${ }^{1, *}$ \\ ${ }^{1}$ Faculty of Chemistry and Chemical Technology, University of Ljubljana, Aškerčeva 5, \\ SI-1000 Ljubljana, Slovenia \\ ${ }^{2}$ Laboratory for Inorganic Chemistry and Technology, National Institute of Chemistry, Hajdrihova 19, \\ SI-1001 Ljubljana, Slovenia \\ *Corresponding author: E-mail: simona.medvescek@fkkt.uni-lj.si
}

Received: 02-02-2017

\begin{abstract}
The effect of limestone on the hydration of Portland cement has been studied by many researchers. However, a possible influence of adding more soluble carbonates was not explained. Therefore we executed a qualitative and quantitative research on the influence of slightly soluble $\left(\mathrm{CaCO}_{3}, \mathrm{MgCO}_{3}\right.$, dolomite), medium soluble $\left(\mathrm{Li}_{2} \mathrm{CO}_{3}\right)$ and highly soluble $\left(\mathrm{K}_{2} \mathrm{CO}_{3}\right.$ and $\mathrm{KHCO}_{3}$ ) carbonates on the hydration.

Blending of Portland cement with differently soluble carbonates was found to influence the hydrate assemblage of the hydrated cement. With the help of the Rietveld analysis, the study indicated that the amount of reacted carbonate in cement hydration at a $15 \%$ addition of slightly or medium soluble carbonates does not exceed 5\% and is not affected by their solubility; at a $15 \%$ addition of the highly soluble carbonate $\mathrm{K}_{2} \mathrm{CO}_{3}$ the amount of reacted carbonate was around $6 \%$.

An increase in temperature $\left(25\right.$ to $\left.40^{\circ} \mathrm{C}\right)$ gradually affects the rate of hydration and the quantity of stable phase assemblage.
\end{abstract}

Keywords: Portland cement; Hydration; Carbonates; Solubility; Rietveld method; Quantitative phase analysis

\section{Introduction}

Over the last 20 years, the effects of using limestone in Portland cement (PC) have been well studied. The benefits of limestone as a partial replacement for PC are well established. Its economic and environmental advantages of reducing $\mathrm{CO}_{2}$ emissions are well known.

However, throughout the years, the general provisions which determine the amount of limestone permitted in cement, have remained unchanged. Most Portland cement specifications allow the use of limestone up to $5 \%$. Beyond that, Portland limestone cements (PLC) are categorized on the basis of the percentage of limestone (6-35\%) added to the cement. The European Standard (EN 197-1-2000) permits up to 5\% limestone regarding it as a minor additional constituent. It also identifies four types of PLC containing 6-20\% limestone (types II/A-L and II/A-LL) and 21-35\% limestone (types II/B-L and II/B-LL), respectively. ${ }^{1}$

For a long time, the limestone has been considered as an inert filler. Recently it has been concluded that lime- stone serves both as an inert filler and also reacts to a limited extend. The reactivity depends on its fineness (specific surface) $)^{2}$ and content. ${ }^{3,4}$

Matschei et al found that at a low concentration, limestone (a molar ratio of $\mathrm{CO}_{2} / \mathrm{Al}_{2} \mathrm{O}_{3} \sim 0.66$ with a fixed sulfate ratio $\mathrm{SO}_{3} / \mathrm{Al}_{2} \mathrm{O}_{3}=1$ and an excess of portlandite, $\mathrm{T}$ $=25{ }^{\circ} \mathrm{C}$ ) reacts completely to various forms of carboaluminate phases. The extension of limestone's reactivity is controlled by the amount of sulphate in the system. As the sulphate content increases, the likelihood of unreacted calcite increases.

It is agreed that limestone reacts primarily with the tricalcium aluminate $\left(\mathrm{C}_{3} \mathrm{~A}\right)$ to form carboaluminates (hemicarboaluminate, $\mathrm{C}_{4} \mathrm{AC}_{0.5} \mathrm{H}_{12}$ and monocarboaluminate, $\mathrm{C}_{4} \mathrm{~A} \overline{\mathrm{C}} \mathrm{H}_{11}$ are the most common) at the expense of hydrates. ${ }^{5,6}$ On the other hand, the formation of ettringite $\left(\mathrm{C}_{6} \mathrm{~A}_{3} \overline{\mathrm{S}} \mathrm{H}_{32}\right)$ in PLC, the hydration reaction of $\mathrm{C}_{3} \mathrm{~A}$ in the presence of gypsum, is still questionable. Some researchers found its formation delayed, while others found that ettringite $(\mathrm{AFt})$ formation proceeded normally. ${ }^{5}$ 
Ramachandran and Zhang, for example, found that the formation of AFt accelerates. ${ }^{7,8}$ The AFt conversion to monosulfate (Ms) will be delayed or stopped when a large amount of carbonate is present in the hydrated paste. This phenomenon occurs due to the fact that some sulfate ions can be interchanged by carbonate ions during the $\mathrm{C}_{3} \mathrm{~A}$ hydration. ${ }^{9,10}$ Thermodynamic calculations as well as experimental observations also indicate that in the presence of $\mathrm{CaCO}_{3}$, monocarboaluminate (Mc) and not $\mathrm{Ms}$ is stable. And even more, the stabilization of $\mathrm{Mc}$ in the presence of limestone caused AFt to stabilize. ${ }^{11}$ In PLC, there is also an interaction between tricalcium silicate $\left(\mathrm{C}_{3} \mathrm{~S}\right)$ and calcium carbonate $\left(\mathrm{CaCO}_{3}\right)$; the latter accelerates the hydration of $\mathrm{C}_{3} \mathrm{~S}$ and modifies the $\mathrm{Ca} / \mathrm{Si}$ ratio of calcium silicate hydrate gel $(\mathrm{C}-\mathrm{S}-\mathrm{H}){ }^{12}$

It is worth noting that limestone does not show pozzolanic properties and, consequently, does not produce $\mathrm{C}-\mathrm{S}-\mathrm{H} .{ }^{13}$ It has been suggested that when large quantities of carbonate are present, some $\mathrm{CaCO}_{3}$ can be incorporated into $\mathrm{C}-\mathrm{S}-\mathrm{H}$ to form calcium silicocarbonate hydrates. ${ }^{5,14}$ The production of portlandite $(\mathrm{CH})$ seems to be enhanced at early ages partly due to dissolution of limestone and also due to limestone's ability to act as nucleation sites. ${ }^{5}$

The important stable phases in hydrated calcite-containing cement are AFt, Mc and calcite. ${ }^{3}$ They are calculated to be stable and present in comparable amounts in the temperature range of $25-40{ }^{\circ} \mathrm{C} . .^{15,16}$

The Rietveld Method enables us to determine the amount of anhydrous and hydrous phases in PC to a high degree of precision. ${ }^{17}$ This method employs a point-topoint adjustment of experimental intensities of the whole pattern to the calculated intensities based on the crystal structures (space groups, types of atoms, their coordinates in the unit cell and site occupancies) present in the mixture and it also provides the weight fractions for each crystalline phase. ${ }^{18,19}$

This paper examines the influence of differently soluble carbonates on the hydration of $\mathrm{PC}$ in the temperature range of $25-40{ }^{\circ} \mathrm{C}$. The quantitative data obtained by using X-ray diffraction to study the hydration products of Portland cement upon addition of slightly soluble $\left(\mathrm{CaCO}_{3}, \mathrm{MgCO}_{3}\right.$, dolomite $)$, medium soluble $\left(\mathrm{Li}_{2} \mathrm{CO}_{3}\right)$ and highly soluble $\left(\mathrm{K}_{2} \mathrm{CO}_{3}\right.$ and $\left.\mathrm{KHCO}_{3}\right)$ carbonates, are compared to similar data from a control sample, based on the same Portland cement paste.

\section{The Experimental}

\section{1. Materials}

Ordinary Portland cement, CEM I 52.2 R (Salonit Anhovo, Building Materials, Joint-Stock Co., Anhovo, Slovenia) was used. The cement consisted of clinker and chemically precipitated gypsum, both ground in the laboratory mill. Chemical and mineralogical compositions of cement are shown in Table 1.
Table 1. Chemical and mineralogical analysis of CEM I 52.2 R.

\begin{tabular}{lccc}
\hline Chemical analysis & \multicolumn{3}{c}{ Mineralogical analysis } \\
\hline Measured $(\mathrm{wt} \%)^{\dagger}$ & & \multicolumn{2}{c}{ Calculated $(\mathrm{wt} \%)^{\ddagger}$} \\
$\mathrm{CaO}$ & 63.3 & & \\
$\mathrm{SiO}_{2}$ & 20.6 & $\mathrm{C}_{3} \mathrm{~S}$ & 54.9 \\
$\mathrm{Al}_{2} \mathrm{O}_{3}$ & 4.71 & $\mathrm{C}_{2} \mathrm{~S}$ & 17.7 \\
$\mathrm{Fe}_{2} \mathrm{O}_{3}$ & 3.50 & $\mathrm{C}_{3} \mathrm{~A}$ & 6.6 \\
$\mathrm{SO}_{3}$ & 3.37 & $\mathrm{C}_{4} \mathrm{AF}$ & 10.7 \\
$\mathrm{MgO}$ & 1.12 & & \\
$\mathrm{~K}_{2} \mathrm{O}$ & 0.87 & & \\
$\mathrm{Na}_{2} \mathrm{O}$ & 0.21 & & \\
$\mathrm{LOI}$ & 1.90 & & \\
Insoluble & 0.37 & & \\
\hline
\end{tabular}

${ }^{\dagger}$ By XRF. ${ }^{*}$ By Bogue equations.

* Standard cement chemistry notation: $\mathrm{S}=\mathrm{SiO}_{2}, \mathrm{C}=\mathrm{CaO}$,

$\mathrm{A}=\mathrm{Al}_{2} \mathrm{O}_{3}, \mathrm{~F}=\mathrm{Fe}_{2} \mathrm{O}_{3}$.

Compressive strength: $36 \mathrm{MPa}$ (2 days), $56.5 \mathrm{MPa}$ (28 days).

The following carbonates were used:

- Calcium carbonate, $\mathrm{CaCO}_{3}$, laboratory reagent, precipitated, 99.1\%, Kemika, Zagreb, Croatia. Specific surface area of $0.7 \mathrm{~m}^{2} / \mathrm{g}$ (micropore area: -), named $\bar{C} \overline{\mathrm{C}}$ hereafter. - Natural, ground calcite, $\mathrm{CaCO}_{3}, 99.6 \%$, Magnesia 448, Magnesia GmbH, Lüneburg, Germany. Specific surface area of $2.1 \mathrm{~m}^{2} / \mathrm{g}$ (micropore area: $0.3 \mathrm{~m}^{2} / \mathrm{g}$ ), named as calcite hereafter.

- Natural, ground magnesite, $\mathrm{MgCO}_{3}, 98.1 \%$, Magnesia 318, Magnesia GmbH, Lüneburg, Germany. Specific surface area of $4.6 \mathrm{~m}^{2} / \mathrm{g}$ (micropore area: $1.0 \mathrm{~m}^{2} / \mathrm{g}$ ).

- Natural, ground dolomite, $\mathrm{CaMg}\left(\mathrm{CO}_{3}\right)_{2}, 99.5 \%$, Magnesia 4179, Magnesia GmbH, Lüneburg, Germany. Specific surface area of $1.7 \mathrm{~m}^{2} / \mathrm{g}$ (micropore area: $0.2 \mathrm{~m}^{2} / \mathrm{g}$ ).

- Lithium carbonate $\left(\mathrm{Li}_{2} \mathrm{CO}_{3}\right)$, potassium carbonate $\left(\mathrm{K}_{2} \mathrm{CO}_{3}\right)$ and potassium hydrogen carbonate $\left(\mathrm{KHCO}_{3}\right)$ were laboratory reagents of $\mathrm{p}$. a. quality.

\section{2. Sample Preparation}

All the starting mixtures $(10.00 \mathrm{~g})$ contained $85 \mathrm{wt} \%$ of Portland cement and $15 \mathrm{wt} \%$ of carbonate to facilitate comparison (the amount of hydrating Portland cement was constant). Portland cement and the added carbonate were homogenized, and deionized water ( $\mathrm{w} / \mathrm{s}$ ratio of 0.5 ) was added. Suspensions were being homogenized with the VibraCell ultrasonic probe (Sonics \& Materials, Inc., USA) for 30 seconds, placed in alkali-resistant flasks, capped airtight and hydrated at $25 \mathrm{C}$ or $40^{\circ} \mathrm{C}$ for $3,7,28$ and 90 days. For reference, Portland cement hydrated under the same conditions.

\section{3. Characterization Techniques}

X-ray powder diffraction data were collected on a PANalytical X'Pert PRO MPD diffractometer (PANalytical B.V., Almelo, the Netherlands) in $\mathrm{CuK}_{\alpha 1}$ configuration from 3 to $702 \vartheta$ in steps of $0.0332 \vartheta$. Full 
range of a linear PSD, having 128 channels, was used and the total counting time was $200 \mathrm{~s}$ per step (53 minutes of data collection per sample).

Identification of the phases, present in the samples, was performed by analyzing the patterns with X'Pert HighScore Plus Ver. 2.1.2 software and Crystallographica Search Match Ver. 3.0.0.5 with a database PDF-2, Release 2011 RDB (International Centre for Diffraction, Oxford Cryosystems).

The quantitative phase analyses of the phases with known structures were performed using the Rietveld method by using Topas Ver. 2.1 program (Bruker AXS, Karlsruhe, Germany). The method of internal standard addition was used to determine the absolute content of identified crystalline phases of the hydrated samples. For this purpose, $40 \%$ of $\alpha-\mathrm{Al}_{2} \mathrm{O}_{3}$, MicroPolish II, $1-\mu \mathrm{m}$ deagglomerated alumina (Buehler Ltd., Lake Bluff, IL) was added to hydrated samples and thoroughly mixed in an agate mortar.

After the specified hydration time, samples were powdered in an agate mortar and analyzed. The XRD phase analyses of the data considered three replications of each treatment, adding up to 384 samples.

\section{Results}

\section{1. Portland Cement (PC)}

The following crystalline or partly crystalline phases were identified in the clear Portland cement and were included into the model for Rietveld refinement: $\mathrm{CH}$ (ICSD code 34241), Aft (ICSD code 16045), Mc (ICSD code 59327), partly crystalline C-S-H (ICSD code 87689), $\mathrm{CaCO}_{3}(\mathrm{C} \overline{\mathrm{C}})$ (ICSD code 73446), after 28 days of hydration also in vaterite modificiation (ICSD code 15879), calcium aluminium hydrate $\mathrm{C}_{3} \mathrm{AH}_{6}$ (ICSD code 202316), unreacted clinker phases $\mathrm{C}_{3} \mathrm{~S}$ (ICSD code
81100), $C_{2} S$ (ICSD code 39006), $\mathrm{C}_{3}$ A (ICSD code 6287), $\mathrm{C}_{4} \mathrm{AF}$ (ICSD code 9197), and substances in traces (below 2\%): $\mathrm{SiO}_{2}$ (S) (ICSD code 67117), gismondine $\mathrm{CAS}_{2} \mathrm{H}_{4}$ (ICSD code 15838) and carbosilicate tilleyite $\mathrm{C}_{3} \mathrm{~S}_{2}(\mathrm{CC})_{2}$ (ICSD code 14256).

In Figure 1 a representative Rietveld plot is presented. At a certain temperature $\left(25\right.$ or $\left.40{ }^{\circ} \mathrm{C}\right)$ and after the hydration process is finished $(3,7,28,90$ days), parts of each individual phase are visible - presented in Figure 2. Each value of a given phase content presents an average of 3 measurements taken. There is also a minimum and a maximum value, so one can picture the discrepancy between the three values included in the calculated average.

In the PC samples most of $\mathrm{CH}(12-14 \%)$ is produced. Its amount is decreased after 90 days of the hydration process, which means that the hydration process is finished. This is also confirmed by the amount of crystalline $\mathrm{C}-\mathrm{S}-\mathrm{H}$, which does not significantly change after 90 days of hydration and the minimal presence (2\% and less) of $\mathrm{C}_{3} \mathrm{~S}$ and $\mathrm{C}_{2} \mathrm{~S}$.

After 90 days, even AFt is no longer being produced; its amount is app. 3.7\% at both temperatures. (Less AFt occurs at $40{ }^{\circ} \mathrm{C}$ after any days of hydration.) The occurrence of $\mathrm{Ms}$ is obviously hampered in the starting stages of hydration, as the amounts of Mc (app. $4 \%$ ) and $\mathrm{CaCO}_{3}$ (app. 1\%) are too high and there is not enough $\mathrm{Al}_{2} \mathrm{O}_{3}$. The amount of $\mathrm{C}_{3} \mathrm{~A}$ is minimal after only 3 days of hydration (app. $0.15 \%$ ), and after 28 days the substance is no longer present. AFt is stabilized in the presence of $\mathrm{Mc}$ and $\bar{C} \bar{C}$.

Hemicarboaluminate $(\mathrm{Hc})$ was not identified even after the 3-day hydration, in spite of the fact that the samples were kept in airtight containers and were not dried with solvents, e.g. acetone or diethyl ether. ${ }^{6}$ The reason might be the air carbonization, which can occur in the airtight containers. We presume that all of the Hc converted into the more stable Mc in the 3-day hydration. The in-

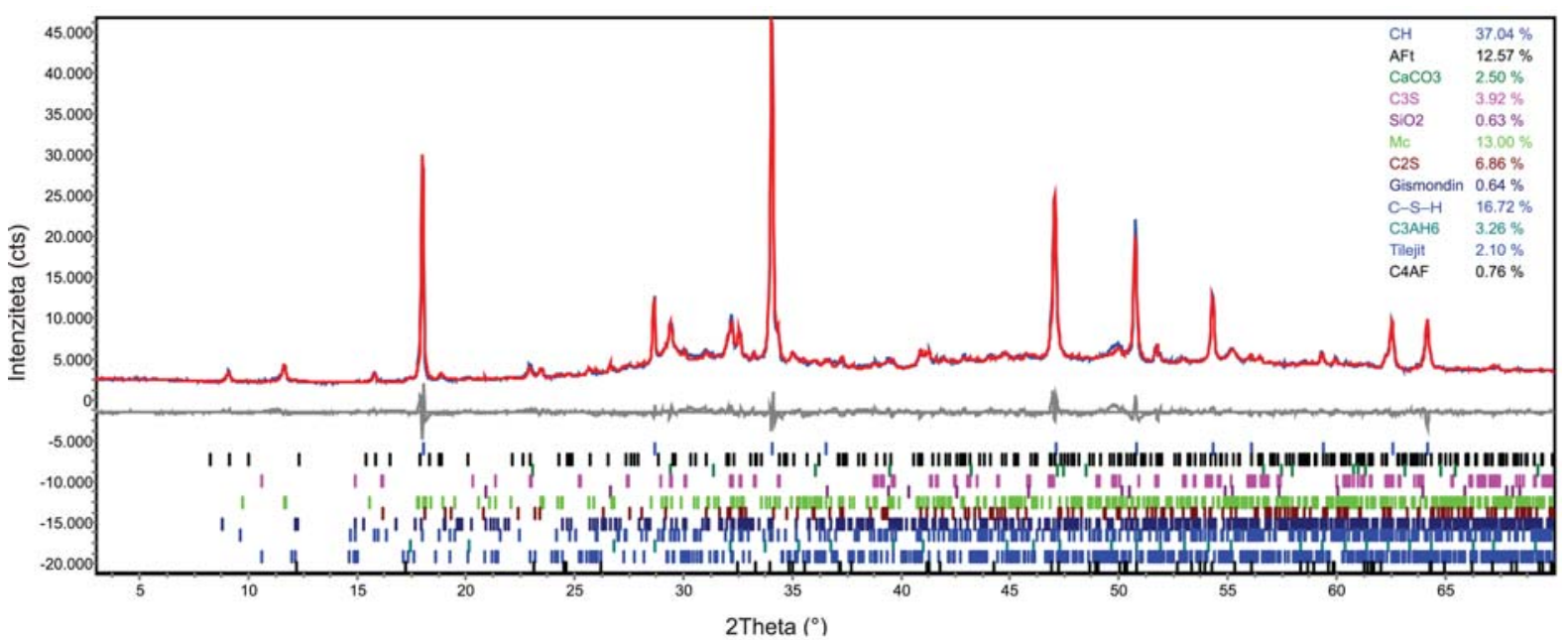

Figure 1. The Rietveld plot of PC, hydrated 90 days. Blue is the measured pattern, red is calculated and grey in the middle is the difference. The vertical bars below denote reflection positions of the included phases. 


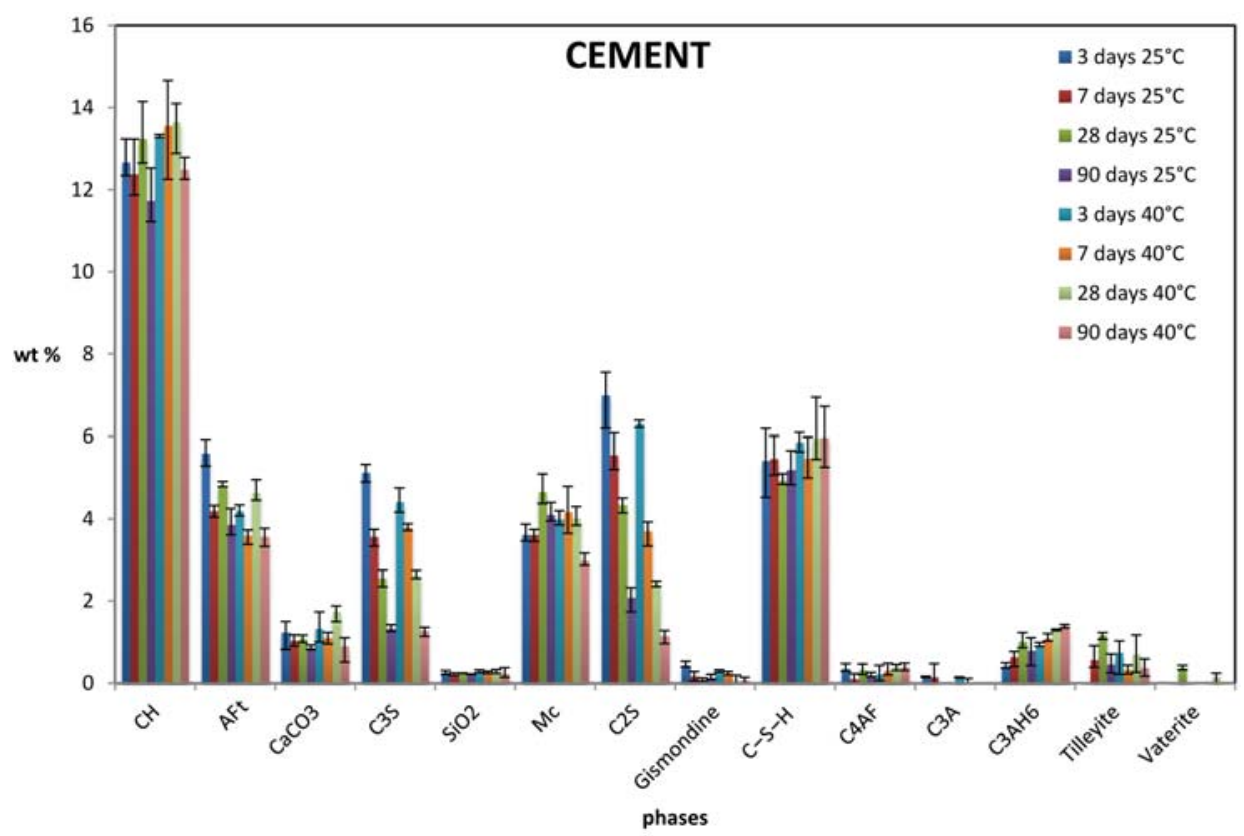

Figure 2. The quantitative analysis of cement hydration at 3, 7, 28 and 90 days of hydration and temperatures of 25 and $40{ }^{\circ} \mathrm{C}$.

creased temperature (from 25 to $40{ }^{\circ} \mathrm{C}$ ) does not influence hydration significantly - it accelerates it a bit. This can be seen in the results of the comparison of the unreacted phases of the cement clinker $\left(\mathrm{C}_{3} \mathrm{~S}, \mathrm{C}_{2} \mathrm{~S}, \mathrm{C}_{3} \mathrm{~A}\right)$ after a certain number of hydration days and the increased amount of $\mathrm{CH}$.

The crystallinity (mass fraction of all crystalline phases in a sample) of PC samples is app. $42 \%$ after 3 days of hydration and is decreased to app. $31 \%$ after 90 days of hydration at both temperatures. The exact values are shown in Table 2.

\section{2. Slightly soluble carbonates}

\section{2. 1. $\mathrm{CaCO}_{3}$, Synthetic and Natural (Solubility at $25{ }^{\circ} \mathrm{C}$ is $6.6 \cdot 10^{-3} \mathrm{~g} / 100 \mathrm{~g}$ Water $^{22}$ )}

Natural $\mathrm{CaCO}_{3}$ (calcite) consists of much smaller particles than synthetic $\mathrm{CaCO}_{3}(\mathrm{C} \overline{\mathrm{C}}), 14 \%$ of the specific surface of calcite consists of micro pores. Calcite has a higher kinetic reactivity and so a faster hydration is expected compared to $C \bar{C}$. In truth, the hydration of the $\mathrm{C}_{3} \mathrm{~S}$ is increased a bit in samples with calcite compared to those with $C \bar{C}$ at any days of hydration at $25{ }^{\circ} \mathrm{C}$ and after the first three days of the hydration at $40{ }^{\circ} \mathrm{C}$, while the reactivity of the calcite particles does not affect the hydration of $\mathrm{C}_{2} \mathrm{~S}$, and after 90 days of hydration there was even more unreacted $\mathrm{C}_{2} \mathrm{~S}$ in the calcite samples at both temperatures. The amount of unreacted $\mathrm{C}_{4} \mathrm{AF}$ is small in calciteadded samples and comparable to those with $C \bar{C}$. It is interesting, that despite the higher reactivity of calcite, after 90 days of hydration of calcite-added samples, there is more unreacted $\mathrm{CaCO}_{3}$ left, compared to samples with $\mathrm{C} \overline{\mathrm{C}}$ at both temperatures. (Samples with $\mathrm{C} \overline{\mathrm{C}}: 10.1 \%$ at $25^{\circ} \mathrm{C}$, $10.9 \%$ at $40{ }^{\circ} \mathrm{C}$; Samples with calcite: $11.6 \%$ at $25^{\circ} \mathrm{C}$,
Table 2. The crystallinity of samples in dependence on the level of hydration and the temperature.

\begin{tabular}{|c|c|c|c|}
\hline sample & $\begin{array}{c}\text { days of } \\
\text { hydration }\end{array}$ & $\begin{array}{c}25^{\circ} \mathrm{C} \\
\%\end{array}$ & $\begin{array}{c}40{ }^{\circ} \mathrm{C} \\
\%\end{array}$ \\
\hline \multirow[t]{4}{*}{$\overline{\mathrm{PC}}$} & 3 & 42 & 42 \\
\hline & 7 & 38 & 38 \\
\hline & 28 & 42 & 38 \\
\hline & 90 & 31 & 31 \\
\hline \multirow[t]{4}{*}{$\mathrm{C} \overline{\mathrm{C}}$} & 3 & 44 & 47 \\
\hline & 7 & 43 & 44 \\
\hline & 28 & 49 & 41 \\
\hline & 90 & 41 & 39 \\
\hline \multirow[t]{4}{*}{ Calcite } & 3 & 43 & 43 \\
\hline & 7 & 44 & 43 \\
\hline & 28 & 45 & 42 \\
\hline & 90 & 43 & 41 \\
\hline \multirow[t]{4}{*}{$\mathrm{MgCO}_{3}$} & 3 & 48 & 49 \\
\hline & 7 & 45 & 43 \\
\hline & 28 & 50 & 45 \\
\hline & 90 & 40 & 41 \\
\hline \multirow[t]{4}{*}{ Dolomite } & 3 & 52 & 49 \\
\hline & 7 & 47 & 50 \\
\hline & 28 & 46 & 48 \\
\hline & 90 & 43 & 43 \\
\hline \multirow{4}{*}{$\mathrm{Li}_{2} \mathrm{CO}_{3}$} & 3 & 53 & 52 \\
\hline & 7 & 54 & 51 \\
\hline & 28 & 53 & 48 \\
\hline & 90 & 49 & 49 \\
\hline \multirow[t]{4}{*}{$\mathrm{KHCO}_{3}$} & 3 & 50 & 50 \\
\hline & 7 & 49 & 47 \\
\hline & 28 & 49 & 48 \\
\hline & 90 & 44 & 44 \\
\hline \multirow[t]{4}{*}{$\mathrm{K}_{2} \mathrm{CO}_{3}$} & 3 & 45 & 50 \\
\hline & 7 & 47 & 46 \\
\hline & 28 & 48 & 47 \\
\hline & 90 & 45 & 45 \\
\hline
\end{tabular}






Figure 3. The quantitative analysis of hydration products in cement with added $\mathrm{C} \overline{\mathrm{C}}$ at $3,7,28$ and 90 days of hydration and two temperatures, 25 and $40{ }^{\circ} \mathrm{C}$.

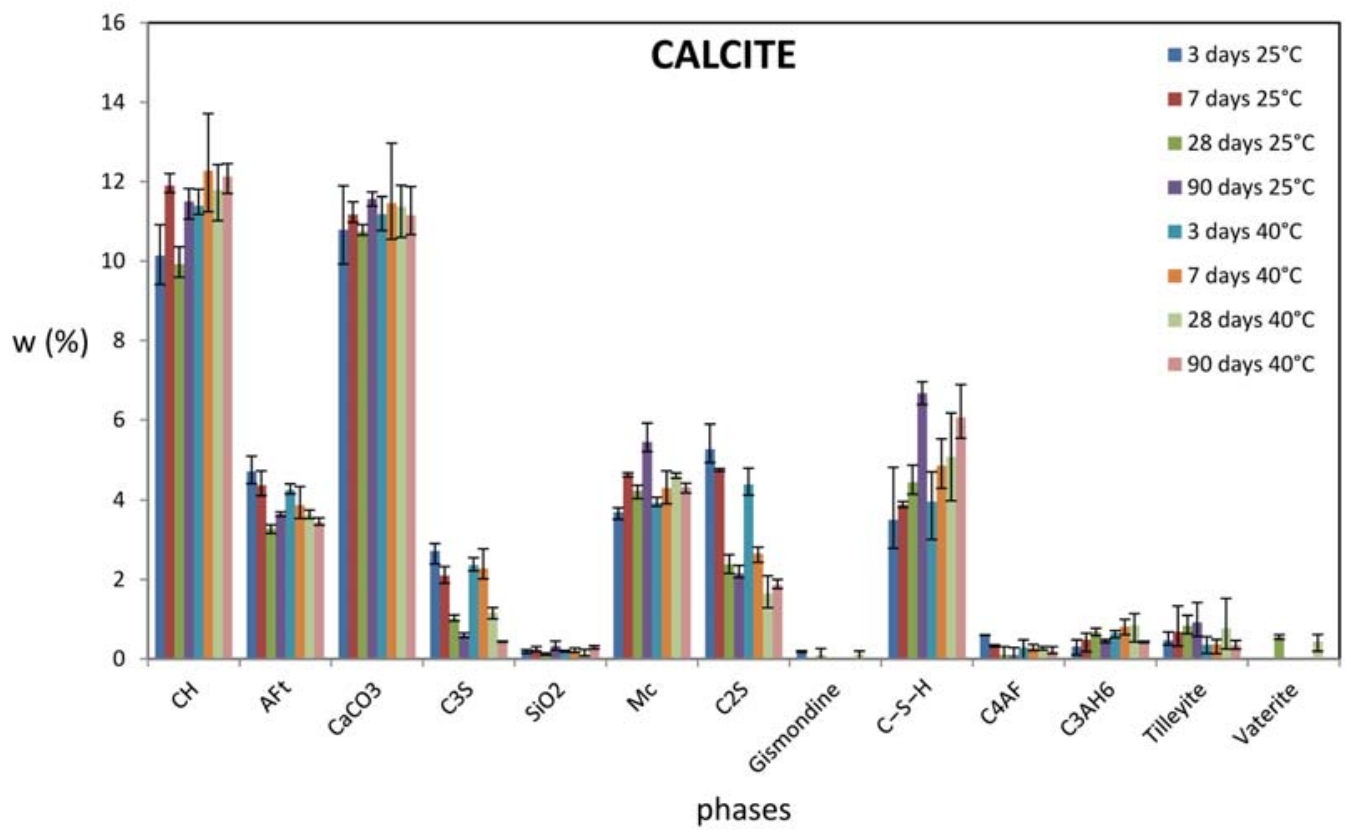

Figure 4. The quantitative analysis of hydration products in cement with added calcite at 3, 7, 28 and 90 days of hydration and two temperatures, 25 and $40{ }^{\circ} \mathrm{C}$.

$11.2 \%$ at $40{ }^{\circ} \mathrm{C}$ ). The amount of the reacted $\mathrm{CaCO}_{3}$ is around $4 \%$, while the rest serves as a filling. This value of the reactive carbonate matches with articles published in the past (up to 5\%), or even a bit higher than suggested by T. Matschei and coworkers (approximately $2.9 \%$ ) regarding the amount of $\mathrm{Al}_{2} \mathrm{O}_{3}$ and relation to $\mathrm{SO}_{3} / \mathrm{Al}_{2} \mathrm{O}_{3}$ in $\mathrm{PC}$. The amount of $\mathrm{AFt}$ after 90 days of hydration in samples with calcite and $C \bar{C}$ is comparable. In fact, we got the same results: $3.6 \%$ at $25{ }^{\circ} \mathrm{C}, 3.4 \%$ at $40{ }^{\circ} \mathrm{C}$. Something similar is true for $\mathrm{Mc}-$ samples with $\mathrm{C} \overline{\mathrm{C}}: 5.4 \%$ at $25^{\circ} \mathrm{C}$,
$3.6 \%$ at $40{ }^{\circ} \mathrm{C}$; samples with calcite: $5.5 \%$ at $25{ }^{\circ} \mathrm{C}, 4.3 \%$ at $40{ }^{\circ} \mathrm{C}$. There are no considerable differences between $C \bar{C}$ - and calcite-added samples regarding the amounts of other hydration products, which is clearly seen by comparing Figures 3 and 4.

The increased temperature (from 25 to $40{ }^{\circ} \mathrm{C}$ ) does not considerably affect hydration. It is just a bit accelerated, which is indicated by the comparison of the reactivity of the cement clinker phases $\left(\mathrm{C}_{3} \mathrm{~S}, \mathrm{C}_{2} \mathrm{~S}\right)$ and thus the formation of an increased amount of $\mathrm{CH}$ and $\mathrm{C}-\mathrm{S}-\mathrm{H}$. The 
formation of $\mathrm{AFt}$ at $40{ }^{\circ} \mathrm{C}$ in the early stages of hydration is possibly somewhat hindered, the AFt contents after 90 days of hydration are comparable at both temperatures. The amount of Mc after 90 days is higher at $25^{\circ} \mathrm{C}$ than at $40{ }^{\circ} \mathrm{C}$ in both samples, with added calcite or $\mathrm{C} \overline{\mathrm{C}}$.

A $15 \%$ addition of carbonate dilutes the cement in the first stages of hydration, which can be seen on the smaller amount of $\mathrm{CH}$ formed in calcite- and $\mathrm{C} \overline{\mathrm{C}}$-added samples. After 90 days the $\mathrm{CH}$ contents are comparable. The hydration of the clinker phases $\left(\mathrm{C}_{3} \mathrm{~S}, \mathrm{C}_{2} \mathrm{~S}, \mathrm{C}_{3} \mathrm{~A}\right)$ is accelerated in samples with added carbonate. The amount of Mc after 90 days is higher in samples with added carbonate. The amount of AFt formed after 90 days of hydration is comparable to that in the samples without added carbonate. After 3 days of hydration at $25{ }^{\circ} \mathrm{C}$ less $\mathrm{AFt}$ is formed in samples with added carbonate, whereas at 40 ${ }^{\circ} \mathrm{C}$ there is no difference. After 7 days of hydration the contents of AFt in all samples (with or without the addition of carbonate) and both temperatures are comparable.
It would be difficult to conclude that the addition of carbonate has any significant influence on the formation of AFt (either impeding the formation or accelerating it). ${ }^{4}$

For a clearer demonstration and possible comparison all contents of the main hydration products $(\mathrm{CH}, \mathrm{AFt}$, Mc and $\mathrm{CaCO}_{3}$ ) are collected in Table 3 in relation to hydration time (3, 7, 28, 90 days) and temperature (25 and $40{ }^{\circ} \mathrm{C}$ ). The minimum and maximum determined contents of the main hydration products are collected bellow, in Table 4 and Table 5.

$\mathrm{C}-\mathrm{S}-\mathrm{H}$ can include $\mathrm{CO}_{3}{ }^{2-}$ anions in its structure, and consequently calcium silicocarbonate hydrates can be formed. We have not identified any with an XRD analysis, but we assume their formation. If the hydration of clinker phases in samples with added calcite or $\mathrm{C} \overline{\mathrm{C}}$ is accelerated, slightly more $\mathrm{SCH}$ should form in these samples than in clear PC samples. Actually we have identified less C-S-H during the hydration in samples with calcite compared to PC samples probably just due to formation of calcium silic-

Table 3. The average compositions of hydration products in relation to hydration time and temperature.

\begin{tabular}{|c|c|c|c|c|c|c|c|c|c|}
\hline \multirow{2}{*}{$\begin{array}{l}\text { temperatu } \\
\text { sample } \\
\text { PC }\end{array}$} & \multirow{2}{*}{$\begin{array}{c}\begin{array}{c}\text { days of } \\
\text { hydration }\end{array} \\
3\end{array}$} & \multicolumn{2}{|c|}{ 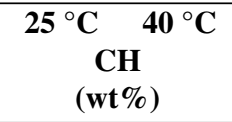 } & \multicolumn{2}{|c|}{$\begin{array}{c}E \\
(w t \%)\end{array}$} & \multicolumn{2}{|c|}{$\begin{array}{c}\mathrm{CaCO}_{3} \\
(\mathrm{wt} \%)\end{array}$} & \multicolumn{2}{|c|}{$\begin{array}{c}\text { Mc } \\
(\mathbf{w t} \%)\end{array}$} \\
\hline & & 12.7 & 13.3 & 5.6 & 4.2 & 1.3 & 1.3 & 3.6 & 4.0 \\
\hline & 7 & 12.4 & 13.6 & 4.2 & 3.6 & 1.0 & 1.1 & 3.6 & 4.2 \\
\hline & 28 & 13.3 & 13.7 & 4.8 & 4.7 & 1.1 & 1.8 & 4.7 & 4.0 \\
\hline & 90 & 11.7 & 12.5 & 3.9 & 3.6 & 0.9 & 0.9 & 4.1 & 3.0 \\
\hline \multirow[t]{4}{*}{$\overline{\mathbf{C} \overline{\mathbf{C}}}$} & 3 & 10.7 & 12.4 & 4.8 & 4.3 & 10.9 & 12.6 & 3.5 & 4.3 \\
\hline & 7 & 11.5 & 12.3 & 4.6 & 3.6 & 10.5 & 11.8 & 4.1 & 4.0 \\
\hline & 28 & 11.3 & 12.2 & 3.5 & 3.9 & 10.5 & 10.7 & 4.9 & 4.3 \\
\hline & 90 & 11.7 & 12.4 & 3.6 & 3.4 & 10.1 & 10.9 & 5.4 & 3.6 \\
\hline \multirow[t]{4}{*}{ calcite } & 3 & 10.1 & 11.4 & 4.7 & 4.3 & 10.8 & 11.2 & 3.70 & 3.9 \\
\hline & 7 & 11.9 & 12.3 & 4.4 & 3.8 & 11.2 & 11.5 & 4.64 & 4.3 \\
\hline & 28 & 9.9 & 11.8 & 3.3 & 3.6 & 10.7 & 11.4 & 4.23 & 4.6 \\
\hline & 90 & 11.5 & 12.1 & 3.6 & 3.4 & 11.6 & 11.2 & 5.47 & 4.3 \\
\hline \multirow{4}{*}{$\mathrm{MgCO}_{3}$} & 3 & 10.3 & 10.3 & 5.2 & 5.1 & 1.8 & 2.4 & 3.8 & 4.6 \\
\hline & 7 & 10.5 & 9.5 & 4.6 & 4.1 & 2.0 & 2.4 & 4.3 & 4.3 \\
\hline & 28 & 9.0 & 10.0 & 3.3 & 4.7 & 4.9 & 5.0 & 4.2 & 4.8 \\
\hline & 90 & 9.0 & 8.8 & 3.5 & 4.5 & 4.6 & 9.6 & 4.6 & 3.7 \\
\hline \multirow[t]{4}{*}{ dolomite } & 3 & 11.2 & 11.6 & 5.1 & 4.0 & 1.8 & 1.9 & 3.6 & 4.0 \\
\hline & 7 & 11.1 & 12.7 & 4.6 & 3.9 & 1.6 & 1.9 & 4.1 & 4.7 \\
\hline & 28 & 10.2 & 12.3 & 3.1 & 4.3 & 1.6 & 2.6 & 4.3 & 5.3 \\
\hline & 90 & 11.6 & 12.2 & 3.6 & 3.9 & 1.7 & 2.5 & 5.4 & 4.6 \\
\hline \multirow[t]{4}{*}{$\overline{\mathrm{Li}_{2} \mathrm{CO}_{3}}$} & 3 & 8.4 & 9.5 & 0.8 & - & 4.3 & 4.8 & 5.4 & 5.2 \\
\hline & 7 & 10.2 & 10.1 & 0.7 & - & 4.5 & 5.3 & 5.6 & 5.6 \\
\hline & 28 & 9.2 & 10.5 & - & - & 6.3 & 5.4 & 4.5 & 5.0 \\
\hline & 90 & 11.6 & 12.0 & - & - & 4.8 & 5.5 & 5.4 & 4.6 \\
\hline \multirow{4}{*}{$\mathrm{KHCO}_{3}$} & 3 & 6.0 & 7.0 & - & - & 9.7 & 10.8 & 8.0 & 6.8 \\
\hline & 7 & 7.5 & 8.5 & - & - & 10.1 & 10.5 & 6.7 & 4.9 \\
\hline & 28 & 9.4 & 11.4 & - & - & 10.6 & 11.6 & 5.4 & 5.6 \\
\hline & 90 & 10.4 & 11.3 & - & - & 10.9 & 12.6 & 6.5 & 5.6 \\
\hline \multirow[t]{4}{*}{$\overline{\mathrm{K}_{2} \mathrm{CO}_{3}}$} & 3 & 9.5 & 11.5 & - & - & 4.7 & 6.2 & 5.3 & 5.0 \\
\hline & 7 & 11.0 & 12.4 & - & - & 5.1 & 5.5 & 3.6 & 5.0 \\
\hline & 28 & 9.0 & 14.1 & - & - & 9.1 & 5.8 & 2.7 & 4.3 \\
\hline & 90 & 13.8 & 15.1 & - & - & 5.6 & 5.8 & 4.6 & 3.9 \\
\hline
\end{tabular}


Table 4. The minimum and maximum contents of hydration products in relation to hydration time and $25^{\circ} \mathrm{C}$.

\begin{tabular}{|c|c|c|c|c|c|c|c|c|c|}
\hline \multirow[t]{2}{*}{ sample } & \multirow{2}{*}{$\begin{array}{l}\text { days of hydration } \\
\text { content } / 25^{\circ} \mathrm{C}\end{array}$} & \multicolumn{2}{|c|}{ CH (wt\%) } & \multicolumn{2}{|c|}{$E(w t \%)$} & \multicolumn{2}{|c|}{$\mathrm{CaCO}_{3}(\mathrm{wt} \%)$} & \multicolumn{2}{|c|}{ Mc (wt\%) } \\
\hline & & minimum & maximum & minimum & maximum & minimum & maximum & minimum & maximum \\
\hline \multirow[t]{4}{*}{$\overline{\mathbf{P C}}$} & 3 & 12.34 & 13.23 & 5.29 & 5.93 & 0.82 & 1.50 & 3.47 & 3.87 \\
\hline & 7 & 11.87 & 13.23 & 4.04 & 4.33 & 0.90 & 1.17 & 3.46 & 3.74 \\
\hline & 28 & 12.65 & 14.15 & 4.78 & 4.91 & 0.99 & 1.17 & 4.37 & 5.09 \\
\hline & 90 & 11.22 & 12.53 & 3.61 & 4.25 & 0.82 & 0.93 & 3.95 & 4.40 \\
\hline \multirow[t]{4}{*}{$\overline{\mathbf{C C}}$} & 3 & 10.43 & 11.05 & 4.61 & 4.87 & 10.76 & 11.16 & 3.29 & 3.61 \\
\hline & 7 & 11.31 & 11.62 & 4.43 & 4.75 & 10.35 & 10.63 & 4.08 & 4.14 \\
\hline & 28 & 10.33 & 12.17 & 3.17 & 3.83 & 10.24 & 10.96 & 4.41 & 5.57 \\
\hline & 90 & 11.26 & 12.51 & 3.21 & 4.05 & 9.76 & 10.52 & 5.25 & 5.68 \\
\hline \multirow[t]{4}{*}{ calcite } & 3 & 9.41 & 10.91 & 4.42 & 5.11 & 9.92 & 11.90 & 3.51 & 3.80 \\
\hline & 7 & 11.72 & 12.20 & 4.11 & 4.73 & 10.98 & 11.49 & 4.59 & 4.68 \\
\hline & 28 & 9.59 & 10.36 & 3.16 & 3.38 & 10.65 & 10.92 & 4.04 & 4.38 \\
\hline & 90 & 11.05 & 11.83 & 3.59 & 3.70 & 11.38 & 11.74 & 5.22 & 5.92 \\
\hline \multirow[t]{4}{*}{$\mathrm{MgCO}_{3}$} & 3 & 9.23 & 11.24 & 4.85 & 5.49 & 1.38 & 2.07 & 3.51 & 4.07 \\
\hline & 7 & 10.26 & 10.80 & 4.29 & 4.99 & 1.89 & 2.25 & 4.20 & 4.50 \\
\hline & 28 & 8.46 & 9.45 & 2.80 & 3.63 & 4.67 & 5.16 & 3.99 & 4.42 \\
\hline & 90 & 8.75 & 9.29 & 3.11 & 3.65 & 4.28 & 4.90 & 4.42 & 4.87 \\
\hline \multirow[t]{4}{*}{ dolomite } & 3 & 10.79 & 11.36 & 4.93 & 5.50 & 1.40 & 2.37 & 3.42 & 3.79 \\
\hline & 7 & 10.75 & 11.56 & 4.29 & 5.00 & 1.49 & 1.67 & 3.94 & 4.29 \\
\hline & 28 & 10.00 & 10.40 & 2.83 & 3.32 & 1.61 & 1.67 & 4.20 & 4.33 \\
\hline & 90 & 10.94 & 11.90 & 3.38 & 3.83 & 1.39 & 1.83 & 5.17 & 5.51 \\
\hline \multirow[t]{4}{*}{$\overline{\mathrm{Li}_{2} \mathrm{CO}_{3}}$} & 3 & 8.04 & 8.70 & 0.66 & 1.12 & 4.14 & 4.61 & 5.08 & 5.83 \\
\hline & 7 & 10.05 & 10.49 & 0.38 & 0.97 & 4.13 & 4.83 & 5.44 & 5.87 \\
\hline & 28 & 8.82 & 9.56 & - & - & 6.06 & 6.59 & 4.30 & 4.68 \\
\hline & 90 & 11.38 & 12.03 & - & - & 4.39 & 5.02 & 5.28 & 5.46 \\
\hline \multirow[t]{4}{*}{$\mathrm{KHCO}_{3}$} & 3 & 5.58 & 6.33 & - & - & 9.49 & 10.14 & 7.28 & 8.76 \\
\hline & 7 & 7.23 & 7.70 & - & - & 9.17 & 10.61 & 6.40 & 6.90 \\
\hline & 28 & 9.31 & 9.40 & - & - & 9.69 & 10.63 & 5.37 & 5.51 \\
\hline & 90 & 10.29 & 10.61 & - & - & 10.11 & 11.99 & 5.63 & 7.37 \\
\hline \multirow[t]{4}{*}{$\mathrm{K}_{2} \mathrm{CO}_{3}$} & 3 & 9.34 & 9.70 & - & - & 4.42 & 5.02 & 5.14 & 5.52 \\
\hline & 7 & 10.77 & 11.25 & - & - & 4.90 & 5.27 & 3.18 & 4.21 \\
\hline & 28 & 8.42 & 9.82 & - & - & 6.49 & 11.54 & 2.48 & 2.86 \\
\hline & 90 & 13.21 & 14.22 & - & - & 5.29 & 6.11 & 4.24 & 5.14 \\
\hline
\end{tabular}

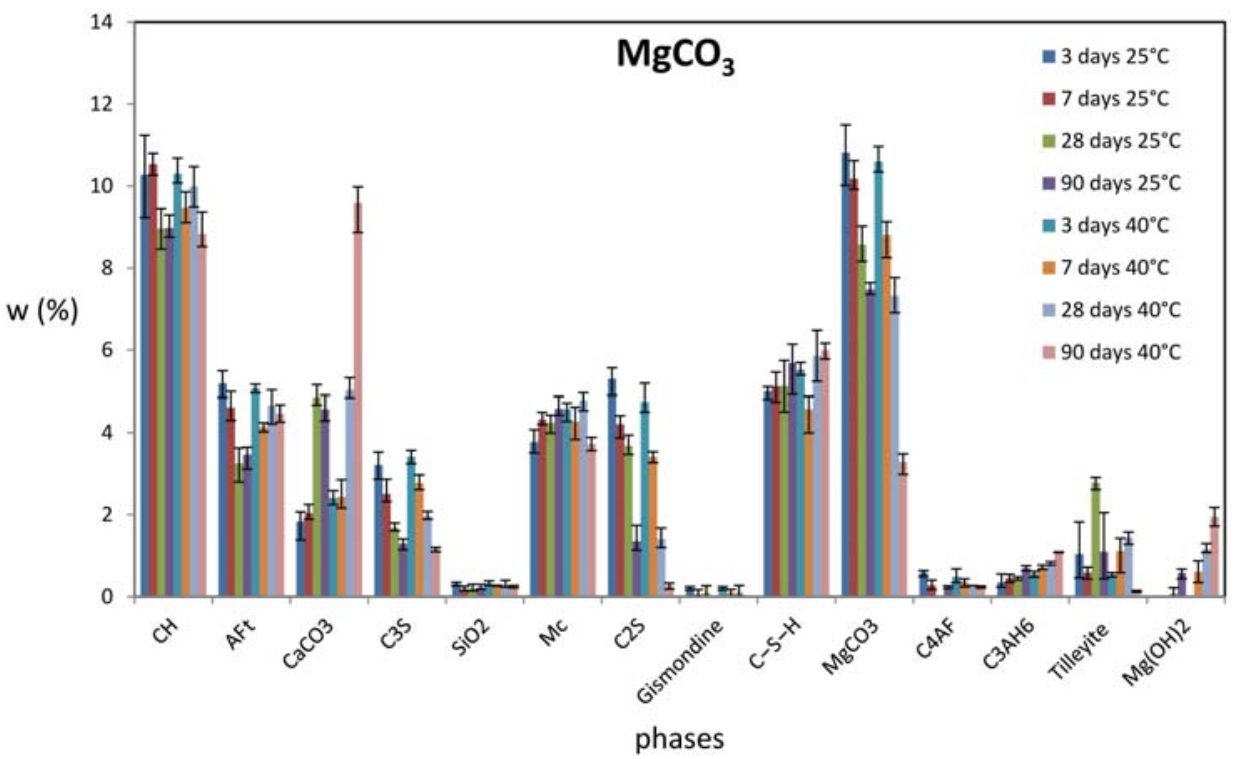

Figure 5. The quantitative determination of hydration products in cements with added $\mathrm{MgCO}^{3}$ at 3, 7, 28 and 90 days of hydration and two temperatures, 25 and $40{ }^{\circ} \mathrm{C}$. 
Table 5. The minimum and maximum contents of hydration products in relation to hydration time and $40{ }^{\circ} \mathrm{C}$.

\begin{tabular}{|c|c|c|c|c|c|c|c|c|c|}
\hline \multirow[t]{2}{*}{ sample } & \multirow{2}{*}{$\begin{array}{l}\text { days of hydration } \\
\text { content } / 40^{\circ} \mathrm{C}\end{array}$} & \multicolumn{2}{|c|}{$\mathrm{CH}(\mathrm{wt} \%)$} & \multicolumn{2}{|c|}{ E (wt\%) } & \multicolumn{2}{|c|}{$\mathrm{CaCO}_{3}(\mathrm{wt} \%)$} & \multicolumn{2}{|c|}{ Mc (wt\%) } \\
\hline & & minimum & maximum & minimum & maximum & minimum & maximum & minimum & maximum \\
\hline \multirow{4}{*}{$\overline{\mathbf{P C}}$} & 3 & 13.27 & 13.35 & 4.07 & 4.34 & 1.00 & 1.73 & 3.85 & 4.20 \\
\hline & 7 & 12.25 & 14.66 & 3.38 & 3.73 & 0.96 & 1.23 & 3.65 & 4.79 \\
\hline & 28 & 12.88 & 14.10 & 4.45 & 4.95 & 1.50 & 1.88 & 3.84 & 4.30 \\
\hline & 90 & 12.25 & 12.79 & 3.33 & 3.77 & 0.51 & 1.10 & 2.87 & 3.17 \\
\hline \multirow[t]{4}{*}{$\overline{\mathbf{C} \overline{\mathbf{C}}}$} & 3 & 12.11 & 12.54 & 4.07 & 4.40 & 12.41 & 12.78 & 4.27 & 4.30 \\
\hline & 7 & 12.15 & 12.46 & 3.26 & 4.05 & 11.77 & 11.83 & 3.86 & 4.03 \\
\hline & 28 & 11.65 & 12.80 & 3.62 & 4.16 & 10.46 & 10.83 & 3.97 & 4.68 \\
\hline & 90 & 12.08 & 12.76 & 3.29 & 3.69 & 10.60 & 11.20 & 3.60 & 3.68 \\
\hline \multirow[t]{4}{*}{ calcite } & 3 & 11.17 & 11.81 & 4.15 & 4.41 & 10.76 & 11.62 & 3.84 & 4.07 \\
\hline & 7 & 11.24 & 13.71 & 3.53 & 4.34 & 10.55 & 12.97 & 3.91 & 4.73 \\
\hline & 28 & 11.02 & 12.43 & 3.53 & 3.75 & 10.60 & 11.91 & 4.55 & 4.68 \\
\hline & 90 & 11.70 & 12.45 & 3.37 & 3.55 & 10.67 & 11.88 & 4.18 & 4.42 \\
\hline \multirow{4}{*}{$\mathrm{MgCO}_{3}$} & 3 & 10.07 & 10.68 & 4.96 & 5.17 & 2.25 & 2.58 & 4.28 & 4.72 \\
\hline & 7 & 9.11 & 9.86 & 4.02 & 4.24 & 2.16 & 2.85 & 3.84 & 4.62 \\
\hline & 28 & 9.66 & 10.18 & 4.30 & 4.85 & 4.68 & 5.67 & 4.74 & 4.86 \\
\hline & 90 & 8.52 & 9.37 & 4.26 & 4.67 & 8.87 & 9.98 & 3.56 & 3.88 \\
\hline \multirow[t]{4}{*}{ dolomite } & 3 & 11.47 & 11.83 & 3.85 & 4.19 & 1.72 & 2.06 & 3.66 & 4.23 \\
\hline & 7 & 12.33 & 13.12 & 3.81 & 3.98 & 1.81 & 1.97 & 4.47 & 4.80 \\
\hline & 28 & 12.07 & 12.59 & 4.21 & 4.35 & 2.25 & 3.09 & 5.08 & 5.44 \\
\hline & 90 & 11.72 & 12.42 & 3.73 & 4.02 & 1.82 & 3.09 & 4.16 & 4.86 \\
\hline \multirow{4}{*}{$\overline{\mathrm{Li}_{2} \mathrm{CO}_{3}}$} & 3 & 8.90 & 9.89 & - & - & 4.44 & 5.02 & 4.67 & 5.58 \\
\hline & 7 & 9.59 & 10.59 & - & - & 4.97 & 5.69 & 5.28 & 5.77 \\
\hline & 28 & 10.31 & 10.75 & - & - & 5.10 & 5.75 & 4.91 & 5.04 \\
\hline & 90 & 11.57 & 12.77 & - & - & 5.33 & 5.79 & 4.32 & 5.07 \\
\hline \multirow[t]{4}{*}{$\mathrm{KHCO}_{3}$} & 3 & 6.60 & 7.29 & - & - & 10.53 & 11.06 & 6.64 & 6.88 \\
\hline & 7 & 8.14 & 8.92 & - & - & 9.91 & 11.13 & 3.21 & 6.63 \\
\hline & 28 & 10.91 & 11.63 & - & - & 11.43 & 11.94 & 5.55 & 5.66 \\
\hline & 90 & 11.00 & 11.69 & - & - & 12.27 & 13.00 & 5.15 & 6.35 \\
\hline \multirow[t]{4}{*}{$\overline{\mathrm{K}_{2} \mathrm{CO}_{3}}$} & 3 & 10.66 & 11.91 & - & - & 6.00 & 6.38 & 3.86 & 6.39 \\
\hline & 7 & 11.96 & 12.65 & - & - & 5.11 & 5.94 & 4.62 & 5.34 \\
\hline & 28 & 13.95 & 14.42 & - & - & 5.51 & 6.03 & 4.06 & 4.59 \\
\hline & 90 & 14.64 & 15.56 & - & - & 5.62 & 5.99 & 3.53 & 4.52 \\
\hline
\end{tabular}

ocarbonate hydrates. After 90 days of hydration the $\mathrm{C}-\mathrm{S}-\mathrm{H}$ contents in the samples with added calcite are comparable to those in the samples of clear PC, whereas the $\mathrm{C}-\mathrm{S}-\mathrm{H}$ contents in the samples with added $\mathrm{C} \overline{\mathrm{C}}$ were still lower compared to samples of clear PC, especially at $25^{\circ} \mathrm{C}$.

The crystallinity of samples with added carbonate does not depend on temperature, after 3 days of hydration it is around $44 \%$ and after 90 days of hydration it is around $41 \%$. Exact values are collected in Table 2. After 3 days of hydration the crystallinity in samples with added carbonate and samples with PC is comparable, whereas after 90 days of hydration the crystallinity of samples with added carbonate is higher than that of PC samples (around 10\%).

\section{2. 2. $\mathrm{MgCO}_{3}$ (Solubility at $25^{\circ} \mathrm{C}$ is $0.18 \mathrm{~g} / 100 \mathrm{~g}$ Water $^{20}$ )}

The hydration products in samples with added $\mathrm{MgCO}_{3}$ are the same as the hydration products in PC sam- ples, with the difference that due to the dissolution of $\mathrm{MgCO}_{3}$ in the presence of $\mathrm{CH}$, the additional formation of $\mathrm{Mg}(\mathrm{OH})_{2}$ occurs after 28 days of hydration at $25^{\circ} \mathrm{C}$ or after 7 days of hydration at $40^{\circ} \mathrm{C}$. (The reaction: $\mathrm{MgCO}_{3}+$ $\left.\mathrm{Ca}(\mathrm{OH})_{2} \rightarrow \mathrm{CaCO}_{3}+\mathrm{Mg}(\mathrm{OH})_{2}\right)$ After 28 days no vaterite forms at $25^{\circ} \mathrm{C}$ as well as at $40^{\circ} \mathrm{C}$. Hydration products and their contents at 3, 7, 28 and 90 days of hydration and both temperatures are demonstrated in Figure 5.

Figure 5 and the above reaction clearly explain that the amount of reacted $\mathrm{MgCO}_{3}$ increases with temperature (after 90 days of hydration: $25{ }^{\circ} \mathrm{C} 7.52 \%, 40{ }^{\circ} \mathrm{C} 11.71 \%$ ). Consequently, at a higher temperature $\mathrm{Mg}(\mathrm{OH})_{2}$ is formed earlier (after 7 days) and in larger amount (90 days hydration: $25{ }^{\circ} \mathrm{C} 0.58 \%, 40{ }^{\circ} \mathrm{C} 1.95 \%$ ). The same holds for $\mathrm{CaCO}_{3}$ and more $\mathrm{CH}$ is being used (see Table 3). The hydration of the clinker phases $\left(\mathrm{C}_{3} \mathrm{~S}, \mathrm{C}_{2} \mathrm{~S}, \mathrm{C}_{3} \mathrm{~A}\right)$ is accelerated. The increased temperature (from 25 to $40{ }^{\circ} \mathrm{C}$ ) accelerates the hydration of $\mathrm{C}_{2} \mathrm{~S}$ after 3 days, whereas the amount of reacted $\mathrm{C}_{3} \mathrm{~S}$ is lerger after 90 days of hydration. In sam- 
ples with added $\mathrm{MgCO}_{3}$ after 90 days of hydration $\mathrm{C}_{3} \mathrm{~S}$ : $25{ }^{\circ} \mathrm{C} 1.30 \%, 40{ }^{\circ} \mathrm{C} 1.17 \%$ and $\mathrm{C}_{2} \mathrm{~S}: 25{ }^{\circ} \mathrm{C} 1.35 \%, 40{ }^{\circ} \mathrm{C}$ $0.27 \%$ remains. Because $\mathrm{CH}$ is being used for the dissolution reaction, there is less of it in samples with added $\mathrm{MgCO}_{3}$ than in samples of clear PC (see Figure 3). More of it is used up during the hydration time at both temperatures $\left(25^{\circ} \mathrm{C}\right.$ at 28 days, $40^{\circ} \mathrm{C}$ at 7 days $)$ for the dilution reaction than is formed during the hydration of calcium di-/tri-silicates. The formation of semi-crystalline $\mathrm{C}-\mathrm{S}-\mathrm{H}$ is unhindered by the addition of $\mathrm{MgCO}_{3}$ and is quantitatively comparable with clear PC samples at both temperatures and all hydration stages (after 90 days of hydration: samples with $\mathrm{MgCO}_{3} 25{ }^{\circ} \mathrm{C} 5.68 \%, 40{ }^{\circ} \mathrm{C} 5.99 \%$; PC samples $25^{\circ} \mathrm{C} 5.19 \%, 40{ }^{\circ} \mathrm{C} 5.99 \%$ ). We could not identify partial formation of calcium silicocarbonate hydrates, but predict them. After 90 days of hydration the AFt contents at both temperatures are comparable to both samples without and with added $\mathrm{MgCO}_{3}$ (see Figure 3). After 90 days of hydration there is a slightly higher amount of formed Mc at both temperatures in samples with added $\mathrm{MgCO}_{3}$ compared to samples of clear PC (Table 3). we can thus conclude that a $15 \%$ addition of $\mathrm{MgCO}_{3}$ at both temperatures does not significantly affect the formation of $\mathrm{AFt}$ and $\mathrm{Mc}$, but it does accelerate the hydration of the clinker phases $\left(\mathrm{C}_{3} \mathrm{~S}, \mathrm{C}_{2} \mathrm{~S}\right.$ in $\left.\mathrm{C}_{3} \mathrm{~A}\right)$. In samples with $\mathrm{MgCO}_{3}$ after 90 days of hydration there is a lot of slightly soluble calcium carbonate $\left(\mathrm{CaCO}_{3}+\mathrm{MgCO}_{3}\right)$ present $\left(25{ }^{\circ} \mathrm{C}\right.$ $12.05 \%, 40{ }^{\circ} \mathrm{C} 12.88 \%$ ), for which we gather that it is unreacted (that is, it serves as a filling) and together with $\mathrm{Mc}$ it only stabilizes the AFt. The amount of reacted calcium carbonate after 90 days of hydration is around $3.7 \%$, which is even slightly less than in samples with added $C \bar{C}$ or calcite. For all samples with the addition of different soluble carbonates are considered that the part of reactive carbonate depends on the molecular weight of added carbonate so it can be calculated from the following equation:

$$
\begin{aligned}
& \mathrm{W}_{\text {(reactive carbonate) }}=15 \% \text { (or inital carbonate content } \\
& \left(\frac{M_{\text {added_carbonate }}}{M_{\text {CaCO }_{3}}} \cdot W_{\text {CaCO }_{3}}+W_{\text {rest_of_added_carbonate }}\right)
\end{aligned}
$$

The added carbonate which is converted into inert $\mathrm{CaCO}_{3}$ is considered to be unreactive.

The $\mathrm{SiO}_{2}$, gismondine, $\mathrm{C}_{4} \mathrm{AF}, \mathrm{C}_{3} \mathrm{AH}_{6}$ and tilleyite portion are small and comparable to samples of clear PC.

The crystallinity of samples with added $\mathrm{MgCO}_{3}$ does not depend on temperature and after 3 days of hydration it is approximately at $49 \%$ and after 90 days of hydration it is around $41 \%$. The exact values are collected in Table 2. The crystallinty in the samples with added $\mathrm{MgCO}_{3}$ is always higher than in PC samples and after 90 days of hydration the values are around $10 \%$ higher than in samples of clear PC.

\section{2. 3. Dolomite}

Hydration products in samples with added dolomite are the same as hydration products in PC samples, with the difference, due to the dilution of dolomite in water, that besides crystallizing $\mathrm{CaCO}_{3}$ on the surface of the dolomite grains $\mathrm{MgCO}_{3}$ crystallizes as well (after 3 and 7 days of hydration at both temperatures). We predict that a small quantity of $\mathrm{MgCO}_{3}$ then reacts with $\mathrm{CH}$ (as in the samples with $\mathrm{MgCO}_{3}$ ), although after 28 as well as 90 days of hydration via the Rietveld method we did not identify the formed $\mathrm{Mg}(\mathrm{OH})_{2}$, due to insufficient quantities. Moreover, we confirmed that there was no dedolomitisation reaction, no expansion reaction between the dolomite and the base $(\mathrm{CH}): \mathrm{CaMg}\left(\mathrm{CO}_{3}\right)_{2}+\mathrm{Ca}(\mathrm{OH})_{2}=$ $\mathrm{Mg}(\mathrm{OH})_{2}+2 \mathrm{CaCO}_{3}$ even after 90 days of hydration at an increased temperature, $40{ }^{\circ} \mathrm{C} .{ }^{21}$ After 28 days vaterite is not formed both at $25{ }^{\circ} \mathrm{C}$ and $40{ }^{\circ} \mathrm{C}$. Hydration products and their contents at 3, 7, 28, 90 days of hydration and both temperatures is clearly visible on Figure 6 . Figure 6 clearly shows the amount of diluted dolomite, which after 90 days of hydration is around $5 \%\left(25{ }^{\circ} \mathrm{C} 4.74 \%, 40^{\circ} \mathrm{C}\right.$ $5.68 \%$ ). Thus, after 90 days of hydration in samples with added dolomite there was a lot of unreacted carbonate present (unreacted dolomite $+\mathrm{CaCO}_{3}: 25{ }^{\circ} \mathrm{C} 11.93 \%$; 40 ${ }^{\circ} \mathrm{C} 11.79 \%$ ). We anticipate that it acts like a filling and at the same time, together with Mc, stabilizes AFt, the portions of which, in samples with or without the added slightly soluble carbonate, are comparable after 90 days of hydration at both temperatures and are around 3.5\% (see Table 3). The amount of reacted carbonate after 90 days of hydration is thus around $1.4 \%$ at both temperatures, which is even lower comparable to samples with added $\mathrm{MgCO}_{3}$ or samples with added $\mathrm{C} \overline{\mathrm{C}} /$ calcite.

The amounts of formed Mc after 90 days of hydration in all samples with added slightly soluble carbonate are comparable (see Table 3). As with other samples with added slightly soluble carbonate the hydration of the clinker phases is accelerated $\left(\mathrm{C}_{3} \mathrm{~S}, \mathrm{C}_{2} \mathrm{~S}, \mathrm{C}_{3} \mathrm{~A}\right)$ and after 90 days the amounts of unreacted di-/tri- silicates are small $\left(\mathrm{C}_{3} \mathrm{~S}: 25{ }^{\circ} \mathrm{C} 0.69 \%, 40{ }^{\circ} \mathrm{C} 0.66 \%\right.$ and $\mathrm{C} 2 \mathrm{~S}: 25{ }^{\circ} \mathrm{C} 2.05 \%$, $40{ }^{\circ} \mathrm{C} 1.24 \%$ ). The amount of the formed $\mathrm{CH}$ is around $12 \%$, after 90 days of hydration, its contents are comparable to those in the samples with added calcium carbonate or $\mathrm{C} \overline{\mathrm{C}}$ (see Table 3), because $\mathrm{CH}$ is not being used up like in samples with added $\mathrm{MgCO}_{3}$. Furthermore, in samples with added dolomite the formation of partly crystalline $\mathrm{C}-\mathrm{S}-\mathrm{H}$ is unhindered and is after 90 days of hydration at both temperatures quantitatively slightly higher than in samples of clear PC or other slightly soluble carbonates $\left(25{ }^{\circ} \mathrm{C} 6.74 \%, 40{ }^{\circ} \mathrm{C} 7.16 \%\right)$. However we assume partial formation of calcium silicocarbonate hydrates but we could not identify them. The amount of $\mathrm{SiO}_{2}$, gismondine, $\mathrm{C}_{4} \mathrm{AF}, \mathrm{C}_{3} \mathrm{AH}_{6}$ and tilleyite are small, their contents do not exceed $1 \%$. The increased temperature (from 25 to $40{ }^{\circ} \mathrm{C}$ ) somewhat accelerates the hydration speed and increases 
the degree of reactivity of the clinker phases $\mathrm{C}_{3} \mathrm{~S}$ and $\mathrm{C}_{2} \mathrm{~S}$. The amount of stable hydration products $(\mathrm{CH}, \mathrm{Mc}, \mathrm{C} \overline{\mathrm{C}})$ is changed slightly during the hydration process, the differences being minor (see Table 3).

The crystallinty of the samples with added dolomite does not depend on temperature. After 3 days of hydration it is around $50 \%$, after 90 days it is around $43 \%$. The exact values are collected in Table 2 . The crystallinity is in the samples with added dolomite always higher than in PC samples and after 90 days of hydration the values exceed the samples with clear PC by $12 \%$.
$5.99 \%$.) After 90 days of hydration around $4 \% \mathrm{Li}_{2} \mathrm{CO}_{3}$ is reacted $\left(25{ }^{\circ} \mathrm{C} 4.07 \%, 40{ }^{\circ} \mathrm{C} 3.8 \%\right)$. Lithium with sulfate ions forms the lithium sulfate hydrate $\mathrm{Li}_{2} \mathrm{SO}_{4}\left(\mathrm{H}_{2} \mathrm{O}\right)$. At both temperatures the contents during the hydration remain low, under $1 \%$, but apparently high enough to not allow the formation of AFt or Ms, probably due to the lack of availability of sulfate ions. AFt only occurs in small amounts (under $1 \%$ ) at $25{ }^{\circ} \mathrm{C}$ during the beginning stages of hydration (after 3 and 7 days), whereas at $40{ }^{\circ} \mathrm{C}$ it does not even occur. The amount of the formed Mc increased, the exact values are collected in Table 3. A part of the alu-

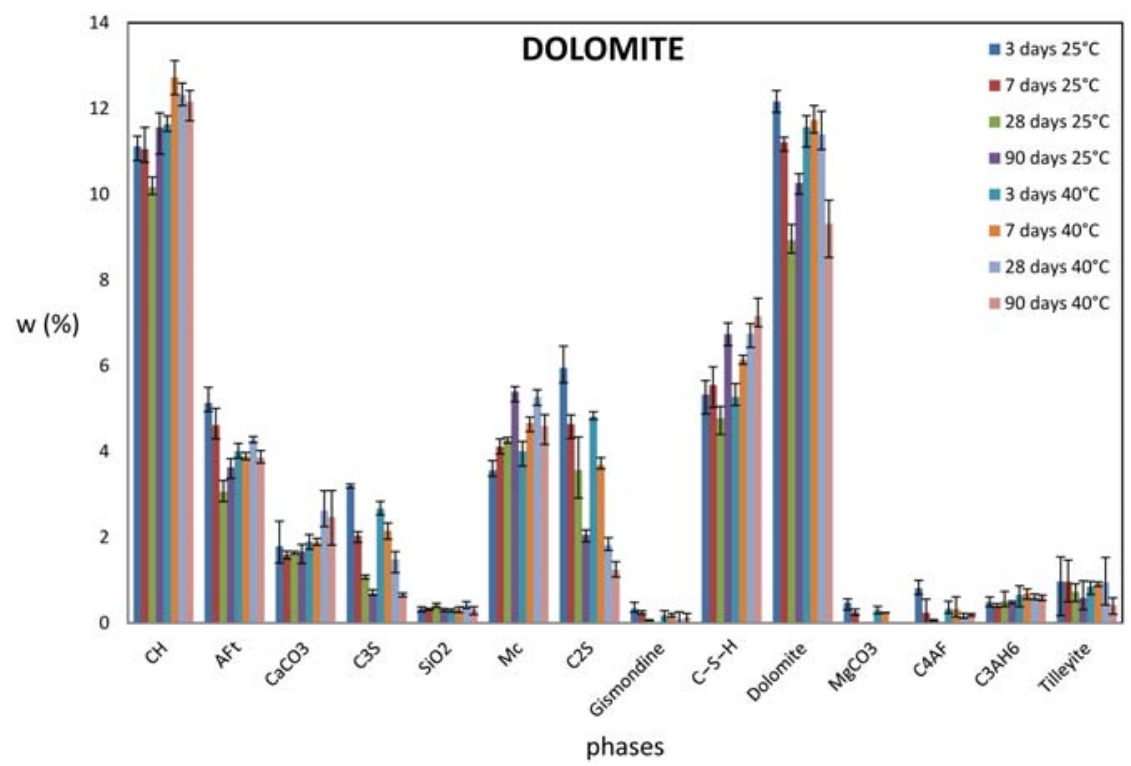

Figure 6. The quantitative analysis of hydration products in cements with added dolomite at 3, 7, 28 and 90 days of hydration and two temperatures, 25 and $40{ }^{\circ} \mathrm{C}$.

\section{3. Medium Soluble Carbonate}

$\mathrm{Li}_{2} \mathrm{CO}_{3}$ (solubility at $25^{\circ} \mathrm{C}$ is $1.30 \mathrm{~g} / 100 \mathrm{~g}$ water ${ }^{20}$ )

A $15 \%$ addition of the moderately soluble carbonate $\mathrm{Li}_{2} \mathrm{CO}_{3}$ affects the cement hydration. With the applied Rietveld method the following phases were identified: $\mathrm{CH}$, $\mathrm{AFt}$ ( 3 and 7 days hydration at $25^{\circ} \mathrm{C}$ ) Mc, partly crystalline $\mathrm{C}-\mathrm{S}-\mathrm{H}, \mathrm{CaCO}_{3}, \mathrm{Li}_{2} \mathrm{CO}_{3}$, calcium aluminum hydrate $\mathrm{C}_{3} \mathrm{AH}_{6}$, unreacted clinker phases $\mathrm{C}_{3} \mathrm{~S}, \mathrm{C}_{2} \mathrm{~S}, \mathrm{C}_{4} \mathrm{AF}$ and compounds in traces (under 2\%): stratlingite $\mathrm{C}_{2} \mathrm{ASH}_{8}$, lithium sulfate hydrate $\mathrm{Li}_{2} \mathrm{SO}_{4}\left(\mathrm{H}_{2} \mathrm{O}\right), \mathrm{SiO}_{2}$, gismondine $\mathrm{CAS}_{2} \mathrm{H}_{4}$ and carbosilicate tilleyite $3 \mathrm{CaO} \cdot \mathrm{SiO}_{2} \cdot 2 \mathrm{CaCO}_{3}$. The hydration of the clinker phases of $\mathrm{C}_{3} \mathrm{~A}$ and $\mathrm{C}_{2} \mathrm{~S}^{22}$ is accelerated, whilst the hydration of $\mathrm{C}_{3} \mathrm{~S}$ at both temperatures is decelerated (see Figure 7). What remains after 90 days of hydration in samples with added $\mathrm{Li}_{2} \mathrm{CO}_{3}$ is $2.44 \%$ of $\mathrm{C}_{3} \mathrm{~S}$ at $25{ }^{\circ} \mathrm{C}$ and $1.78 \%$ of $\mathrm{C}_{3} \mathrm{~S}$ at $40{ }^{\circ} \mathrm{C}$. $\left(\mathrm{C}_{3} \mathrm{~S}\right.$ in $\mathrm{PC}$ after 90 days: $25{ }^{\circ} \mathrm{C} 1.33 \%$; $40{ }^{\circ} \mathrm{C} 1.28 \%$.) Consequently, the amount of formed $\mathrm{C}-\mathrm{S}-\mathrm{H}$ is increased and the differences between samples with and without the added $\mathrm{Li}_{2} \mathrm{CO}_{3}$ increase with the level of hydration. After 90 days of hydration in samples with $\mathrm{Li}_{2} \mathrm{CO}_{3}$ at $25^{\circ} \mathrm{C}$ there is $8.58 \%$ and at $40{ }^{\circ} \mathrm{C}$ there is $8.22 \% \mathrm{C}-\mathrm{S}-\mathrm{H}$. (PC $25{ }^{\circ} \mathrm{C} 5.19 \%$; $40{ }^{\circ} \mathrm{C}$ minum is used for the formation of stratlingite $\mathrm{C}_{2} \mathrm{ASH}_{8}$ (the contents during the 90 days of hydration at both temperatures do not exceed $1 \%$ ). We propose that a part of $\mathrm{Li}_{2} \mathrm{CO}_{3}$ dilutes in $\mathrm{CH}$, through which $\mathrm{CaCO}_{3}$ precipitates (its contents increase with hydration levels and increased temperature and are collected in Table 3), as the contents of $\mathrm{CH}$ after 3, 7 and 28 days of hydration are too low with regard to the high amounts of formed $\mathrm{C}-\mathrm{S}-\mathrm{H}$ or the reactivity of di-/tri- silicates. After 90 days, the amount of formed $\mathrm{CH}$ at both temperatures (around $12 \%$, the exact values are collected in Table 3 ) is comparable to samples with added slightly soluble calcium carbonate and $\mathrm{C} \overline{\mathrm{C}}$. In samples with $\mathrm{Li}_{2} \mathrm{CO}_{3}$ after 90 days of hydration there is a lot of carbonate present $\left(\mathrm{Li}_{2} \mathrm{CO}_{3}+\mathrm{CaCO}_{3}: 25{ }^{\circ} \mathrm{C} 15.72 \%\right.$; $40{ }^{\circ} \mathrm{C} 16.74 \%$ ), for which we propose that its role in the later stages of cement hydration is predominantly an inert filling. After 90 days of hydration there is no reactive carbonate present in the samples with added $\mathrm{Li}_{2} \mathrm{CO}_{3}$, which means that all dissolved $\mathrm{Li}_{2} \mathrm{CO}_{3}$ (about $4 \%$ ) is transformed into stable/ inert $\mathrm{CaCO}_{3}$.

The portions of $\mathrm{SiO}_{2}$, gismondine, $\mathrm{C}_{4} \mathrm{AF}, \mathrm{C}_{3} \mathrm{AH}_{6}$ and tilleyite are relatively minor, not exceeding $2 \%$. The 
increased temperature (from 25 to $40{ }^{\circ} \mathrm{C}$ ) somewhat accelerates the hydration speed and increases the degree of reactivity of the clinker phases. The amount of stable hydration products $(\mathrm{CH}, \mathrm{Mc}, \mathrm{C} \overline{\mathrm{C}})$ is changed slightly during the hydration process, the differences being minor, around $1 \%$ or less (see Table 3 ).

The crystallinity of the samples with added $\mathrm{Li}_{2} \mathrm{CO}_{3}$ does not depend on temperature. After 3 days of hydration it is around $53 \%$ and after 90 days of hydration it is $49 \%$. The exact values are collected in Table 2 . The crystallinity in the samples with added medium soluble carbonates is after 90 days of hydration there is some more reacted $\mathrm{C}_{3} \mathrm{~S}$ than in PC. (90 days hydration: $\mathrm{KHCO}_{3} 25^{\circ} \mathrm{C} 1.52 \%, 40$ ${ }^{\circ} \mathrm{C} 0.40 \%$; PC $25{ }^{\circ} \mathrm{C} 1.33 \%, 40{ }^{\circ} \mathrm{C} 1.28 \%$.) The amount of formed $\mathrm{C}-\mathrm{S}-\mathrm{H}$ is increased and the differences compared with clear PC only increase with hydration stages. The amounts of the formed $\mathrm{C}-\mathrm{S}-\mathrm{H}$ are at both temperatures comparable and are slightly higher at $40{ }^{\circ} \mathrm{C}$ (See Figure 8). After 90 days of hydration in the samples with $\mathrm{KHCO}_{3}$ there is $7.56 \% \mathrm{C}-\mathrm{S}-\mathrm{H}$ at $25{ }^{\circ} \mathrm{C}$ and $7.76 \%$ at $40{ }^{\circ} \mathrm{C}$. (PC $25{ }^{\circ} \mathrm{C} 5.19 \%$; $40{ }^{\circ} \mathrm{C} 5.99 \%$.) Already after 3 days of hydration at both temperatures no $\mathrm{KHCO}_{3}$ is visible. The hy-

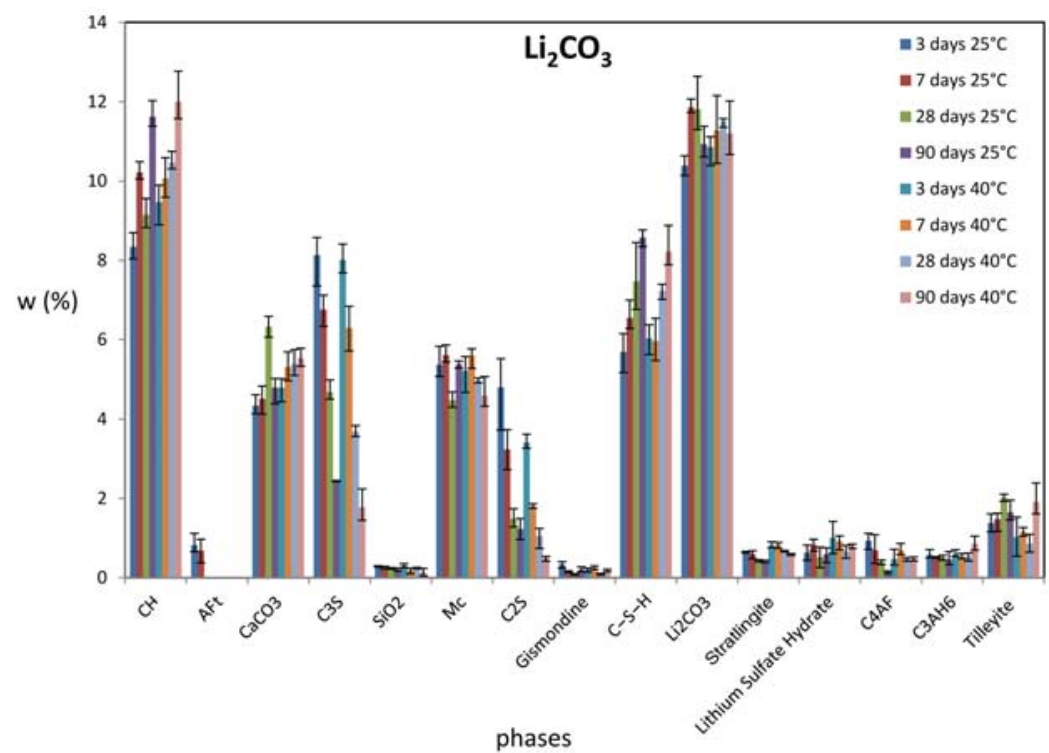

Figure 7. The quantitative analysis of hydration products in cements with added $\mathrm{Li}_{2} \mathrm{CO}_{3}$ at 3, 7, 28 and 90 days of hydration and two temperatures, 25 and $40{ }^{\circ} \mathrm{C}$.

always higher than in PC samples. After 90 days of hydration the values are $18 \%$ higher compared to samples with clear PC. This is attributed to the high amounts of the present carbonate $\left(\mathrm{Li}_{2} \mathrm{CO}_{3}+\mathrm{CaCO}_{3}\right)$ in samples with added $\mathrm{Li}_{2} \mathrm{CO}_{3}$.

\section{4. Highly Soluble Carbonates}

\section{4. 1. $\mathrm{KHCO}_{3}$}

A $15 \%$ addition of the highly soluble carbonate $\mathrm{KHCO}_{3}$ significantly affects the cement hydration due to the high solubility and its important role in changing the $\mathrm{pH}$-value (towards making it less basic). With the applied Rietveld method the following phases were identified: $\mathrm{CH}$, Mc, partly crystalline $\mathrm{C}-\mathrm{S}-\mathrm{H}, \mathrm{CaCO}_{3}, \mathrm{~K}_{2} \mathrm{SO}_{4}$, calcium aluminum hydrate $\mathrm{C}_{3} \mathrm{AH}_{6}$, unreacted clinker phases $\mathrm{C}_{3} \mathrm{~S}, \mathrm{C}_{2} \mathrm{~S}, \mathrm{C}_{4} \mathrm{AF}$ and compounds in traces (under $2 \%$ ): $\mathrm{SiO}_{2}$, gismondine $\mathrm{CAS}_{2} \mathrm{H}_{4}$ and carbosilicate tilleyite $3 \mathrm{CaO} \cdot \mathrm{SiO}_{2} \cdot 2 \mathrm{CaCO}_{3}$. The hydration of the clinker phases $\left(\mathrm{C}_{3} \mathrm{~A}\right.$ in $\left.\mathrm{C}_{2} \mathrm{~S}\right)$ is accelerated, whereas the hydration of $\mathrm{C}_{3} \mathrm{~S}$ is decelerated. It reaches contents comparable with those in PC only after 90 days of hydration at $25^{\circ} \mathrm{C}$ and at $40{ }^{\circ} \mathrm{C}$ dration products make it clear that part of $\mathrm{KHCO}_{3}$ reacts with gypsum $\left(\mathrm{CaSO}_{4} \cdot 2 \mathrm{H}_{2} \mathrm{O}\right)$ at both temperatures, during which $\mathrm{K}_{2} \mathrm{SO}_{4}$ and $\mathrm{CaCO}_{3}$ is formed. Apparently the entire available sulfate in gypsum is used for the formation of $\mathrm{K}_{2} \mathrm{SO}_{4}$ during the reaction, thus we predict that the formation of $\mathrm{AFt}$ or $\mathrm{Ms}$ is hindered. After 90 days at $25^{\circ} \mathrm{C}$ in samples with $\mathrm{KHCO}_{3}$ there is $3.40 \% \mathrm{~K}_{2} \mathrm{SO}_{4}$ present and at $40{ }^{\circ} \mathrm{C}$ there is $3.31 \% \mathrm{~K}_{2} \mathrm{SO}_{4}$ present. The amount of formed Mc increased, the values are collected in Table 3. The $\mathrm{CH}$ contents are low at both temperatures during the hydration process (see Table 3 ) compared to the high amounts of formed $\mathrm{C}-\mathrm{S}-\mathrm{H}$ or the reactivity di-/tri- silicates. We anticipate the $\mathrm{KHCO}_{3}$ dissolving in $\mathrm{CH}$ and furthermore the $\mathrm{CH}$ reacting with dissolved $\mathrm{CO}_{2}$ during which $\mathrm{CaCO}_{3}$ is formed (the contents are collected in Table 3). Thus, in samples with $\mathrm{KHCO}_{3}$ after 90 days of hydration there is $25{ }^{\circ} \mathrm{C} 10.92 \% \mathrm{CaCO}_{3}$ present and $12.57 \%$ at $40{ }^{\circ} \mathrm{C}$. The amount of reactive carbonate is around $3 \%$.

The amounts of $\mathrm{SiO}_{2}$, gismondine, $\mathrm{C}_{4} \mathrm{AF}, \mathrm{C}_{3} \mathrm{AH}_{6}$ and tilleyite are small, not exceeding $2 \%$. At a higher temperature (from 25 to $40{ }^{\circ} \mathrm{C}$ ) the amount of the reacted 


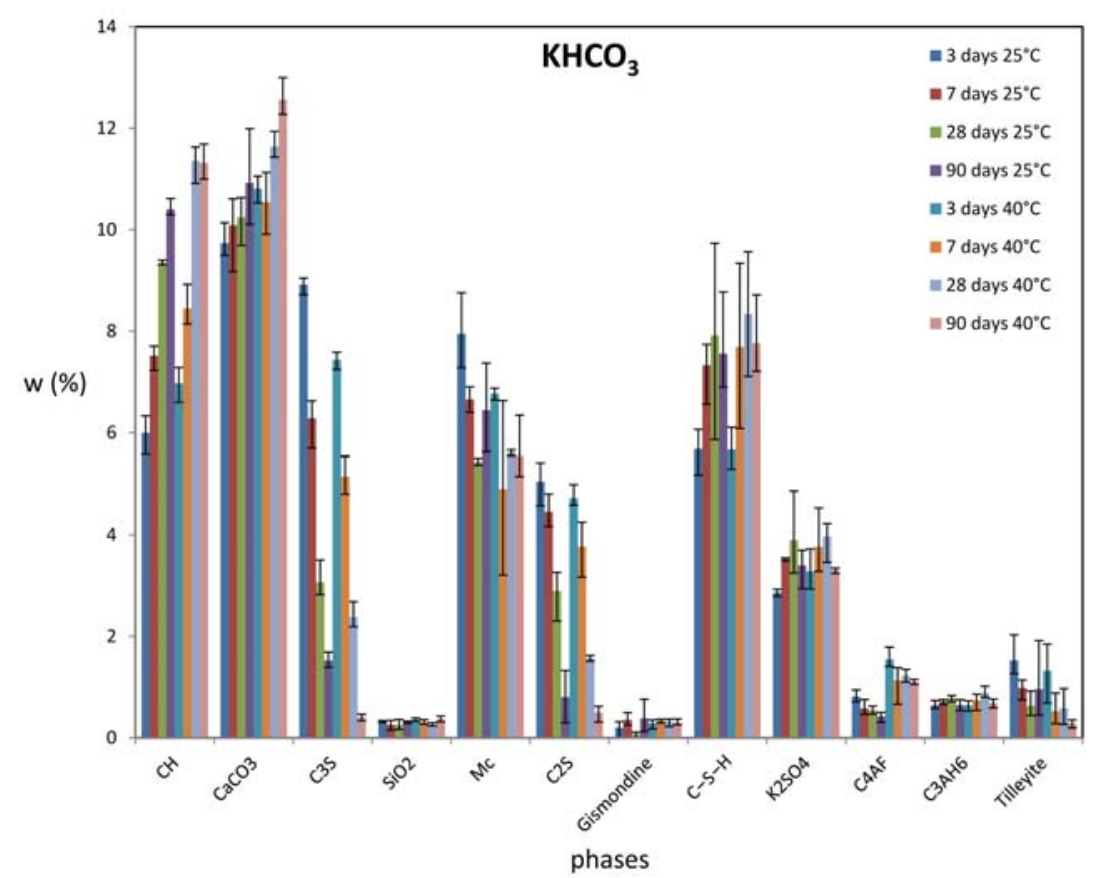

Figure 8. The quantitative analysis of hydration products in cements with added $\mathrm{KHCO}_{3}$ at 3, 7, 28 and 90 days of hydration and two temperatures, 25 and $40{ }^{\circ} \mathrm{C}$.

clinker phases $\mathrm{C}_{3} \mathrm{~S}$ and $\mathrm{C}_{2} \mathrm{~S}$ is higher, which is consequently shown on a higher amount of hydration products $(\mathrm{CH}, \mathrm{C}-\mathrm{S}-\mathrm{H})-$ Figure 8 . At $40{ }^{\circ} \mathrm{C}$ the amount of $\mathrm{CaCO}_{3}$ is slightly higher during the hydration process as there was more $\mathrm{CH}$ available, which could then react with dissolved $\mathrm{CO}_{2}$.

The crystallinity of samples with added $\mathrm{KHCO}_{3}$ does not depend on temperature. After 3 days of hydration it is $50 \%$ and after 90 days of hydration it is $44 \%$. The exact values are collected in Table 2 . The crystallinity in samples with added $\mathrm{KHCO}_{3}$ is always higher compared to PC samples and after 90 days of hydration the values exceed those of clear PC samples by $13 \%$.

\section{4. $2 . \mathrm{K}_{2} \mathrm{CO}_{3}$}

A $15 \%$ addition of the highly soluble carbonate $\mathrm{K}_{2} \mathrm{CO}_{3}$ significantly affects the cement hydration. With the applied Rietveld method the following phases were identified: $\mathrm{CH}$, Mc, partly crystalline $\mathrm{C}-\mathrm{S}-\mathrm{H}, \mathrm{CaCO}_{3}$, $\mathrm{K}_{2} \mathrm{SO}_{4}, \mathrm{~K}_{2} \mathrm{CO}_{3}$, calcium aluminum hydrate $\mathrm{C}_{3} \mathrm{AH}_{6}$, unreacted clinker phases $\mathrm{C}_{3} \mathrm{~S}, \mathrm{C}_{2} \mathrm{~S}, \mathrm{C}_{4} \mathrm{AF}$ and compounds in traces (under 2\%): $\mathrm{SiO}_{2}$, gismondine $\mathrm{CAS}_{2} \mathrm{H}_{4}$ and carbosilicate tilleyite $3 \mathrm{CaO} \cdot \mathrm{SiO}_{2} \cdot 2 \mathrm{CaCO}_{3}$. The hydration of the clinker phases $\left(\mathrm{C}_{3} \mathrm{~A}\right.$ and $\left.\mathrm{C}_{2} \mathrm{~S}\right)$ is accelerated, whereas the hydration of $\mathrm{C}_{3} \mathrm{~S}$ is decelerated in the first stages of the hydration ( 3 and 7 days), but after 28 in 90 days of hydration it is accelerated at both temperatures. (90 days hydration: $\mathrm{K}_{2} \mathrm{CO}_{3} 25^{\circ} \mathrm{C} 0.88 \%, 40{ }^{\circ} \mathrm{C} 0.37 \%$; PC $25^{\circ} \mathrm{C} 1.33 \%$, $40{ }^{\circ} \mathrm{C} 1.28 \%$.) The amount of the formed $\mathrm{C}-\mathrm{S}-\mathrm{H}$ is increased and the difference after 90 days of hydration is 5
$\%$ higher compared to clear PC samples. $\left(\mathrm{K}_{2} \mathrm{CO}_{3}: 25^{\circ} \mathrm{C}\right.$ $10.63 \%, 40{ }^{\circ} \mathrm{C} 10.47 \%$; PC: $25{ }^{\circ} \mathrm{C} 5.19 \%, 40{ }^{\circ} \mathrm{C} 5.99 \%$.) The hydration products make it clear (see Figure 9) that $\mathrm{K}_{2} \mathrm{CO}_{3}$ at both temperatures reacts with gypsum $\left(\mathrm{CaSO}_{4}\right.$. $2 \mathrm{H}_{2} \mathrm{O}$ ), at which point $\mathrm{K}_{2} \mathrm{SO}_{4}$ is formed. The entire available sulfate is apparently used for the formation of $\mathrm{K}_{2} \mathrm{SO}_{4}$ and thus the formation of $\mathrm{AFt}$ or Ms is indirectly hindered. After 90 days at $25{ }^{\circ} \mathrm{C}$ in samples with $\mathrm{K}_{2} \mathrm{CO}_{3}$ there is $5.03 \%$ of $\mathrm{K}_{2} \mathrm{SO}_{4}$ present and $4.82 \%$ at $40{ }^{\circ} \mathrm{C}$. A part of $\mathrm{K}_{2} \mathrm{CO}_{3}$ remains unreacted, but the amount after 90 days of hydration at both temperatures is small, not exceeding $1.5 \%\left(25^{\circ} \mathrm{C} 1.29 \%, 40{ }^{\circ} \mathrm{C} 1.22 \%\right)$. The amount of formed $\mathrm{Mc}$ is minimally increased after 90 days of hydration at both temperatures, the values are collected in Table 3 . The $\mathrm{CH}$ amounts in the beginning stages of hydration ( 3 and 7 days at $25{ }^{\circ} \mathrm{C}$ and 3 days at $40{ }^{\circ} \mathrm{C}$ ) are low compared to the high amounts of formed C-S-H or reactivity of di-/trisilicates. Thus we predict that a part of $\mathrm{K}_{2} \mathrm{CO}_{3}$ dilutes in $\mathrm{CH}$ during the beginning phases of hydration, during which $\mathrm{CaCO}_{3}$ is formed. After 90 days of hydration at 25 ${ }^{\circ} \mathrm{C}$ and 28 days of hydration at $40{ }^{\circ} \mathrm{C}$ the $\mathrm{CH}$ is not being used up anymore and so the contents of $\mathrm{CH}$ exceed those in clear PC (see Table 3). In samples with $\mathrm{K}_{2} \mathrm{CO}_{3}$ after 90 days of hydration there is around $7 \%$ calcium $\left(\mathrm{K}_{2} \mathrm{CO}_{3}+\right.$ $\mathrm{CaCO}_{3}: 25{ }^{\circ} \mathrm{C} 6.91 \%$; $40{ }^{\circ} \mathrm{C} 7 \%$ ) present for which we predict that it serves as an inert filling during the later stages of the cement hydration process. The amount of reactive carbonate is after 90 days of hydration and the both temperatures around $6 \%$.

The amounts of $\mathrm{SiO}_{2}$, gismondine, $\mathrm{C}_{4} \mathrm{AF}, \mathrm{C}_{3} \mathrm{AH}_{6}$ and tilleyite are small, not exceeding $2 \%$. At an increased 


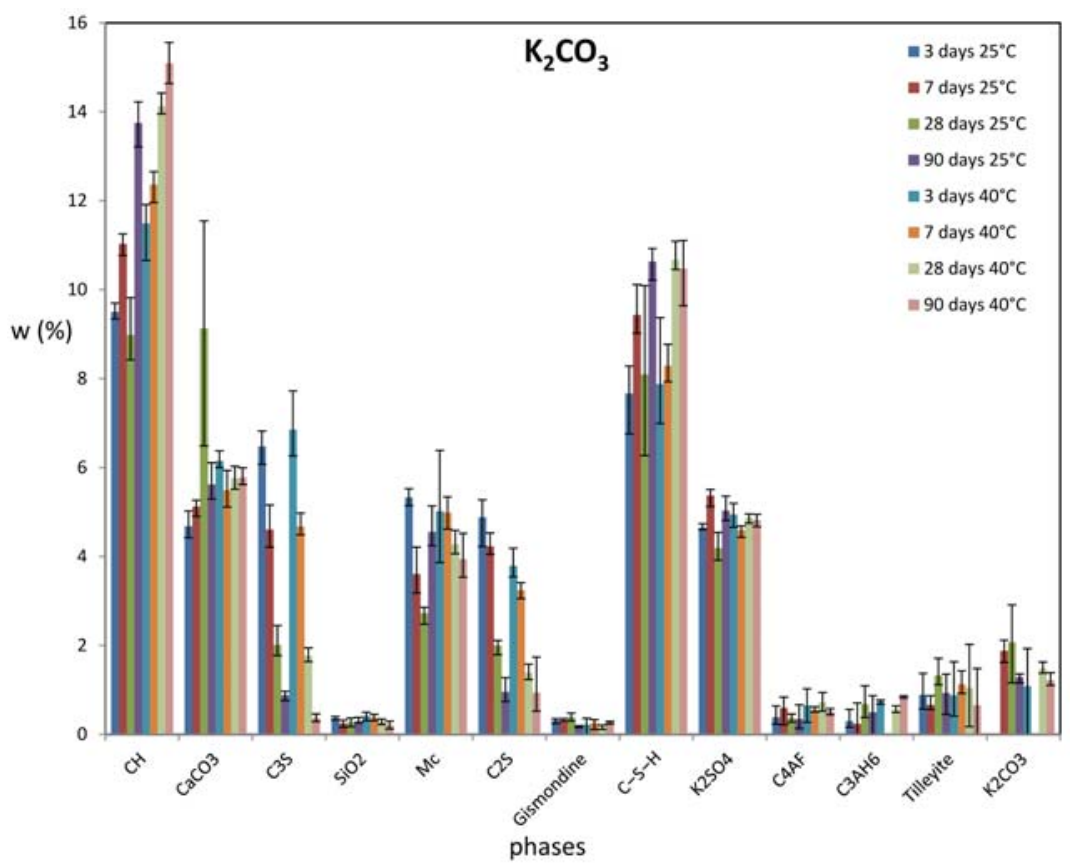

Figure 9. The quantitative analysis of hydration products in cements with added $\mathrm{K}_{2} \mathrm{CO} 3$ at 3, 7, 28 and 90 days of hydration and two temperatures, 25 and $40{ }^{\circ} \mathrm{C}$.

temperature (from 25 to $40^{\circ} \mathrm{C}$ ) the reactivity of the clinker phase $\mathrm{C}_{2} \mathrm{~S}$ is slightly higher, whereas the majority of the reacted $\mathrm{C}_{3} \mathrm{~S}$ is only visible after 28 days of hydration (see Figure 9).

The crystallinity of the samples with added $\mathrm{K}_{2} \mathrm{CO}_{3}$ does not depend on temperature. After 3 days it is between 45 and $50 \%$ and after 90 days of hydration it is $45 \%$. The exact values are collected in Table 2 . The crystallinity in samples with added $\mathrm{K}_{2} \mathrm{CO}_{3}$ is always higher compared to PC samples and after 90 days of hydration the values exceed those of clear PC samples by $14 \%$.

\section{Discussion}

Results presented above show that the addition of differently soluble carbonates does have an influence on cement hydration, the higher the solubility the more obvious the differences are (see Figure 10).

Hydration process and the contents of stable hydration products do not change significantly in the temperature range 25 to $40{ }^{\circ} \mathrm{C}$. The hydration of the clinker phases $\left(\mathrm{C}_{3} \mathrm{~A}, \mathrm{C}_{3} \mathrm{~S}\right.$ and $\left.\mathrm{C}_{2} \mathrm{~S}\right)$ is at $40{ }^{\circ} \mathrm{C}$ somewhat accelerated and the amount of stable phases ( $\mathrm{E}$ in slightly soluble carbonates, $\mathrm{Mc}, \mathrm{CH}$, calcite and $\mathrm{C}-\mathrm{S}-\mathrm{H}$ ) of cement hydration is slightly changed. Presence of stable phases in our samples confirm T. Matschei calculations. ${ }^{3}$

Slightly soluble carbonates $\left(\bar{C}\right.$, calcite, $\mathrm{MgCO}_{3}$, dolomite) accelerate the hydration of the clinker phases $\mathrm{C}_{3} \mathrm{~A}, \mathrm{C}_{3} \mathrm{~S}$ and $\mathrm{C}_{2} \mathrm{~S}$. Medium soluble $\left(\mathrm{Li}_{2} \mathrm{CO}_{3}\right)$ and highly soluble $\left(\mathrm{KHCO}_{3}, \mathrm{~K}_{2} \mathrm{CO}_{3}\right)$ carbonates accelerate the hydra- tion of $\mathrm{C}_{3} \mathrm{~A}$ and $\mathrm{C}_{2} \mathrm{~S}$, whereas the hydration of $\mathrm{C}_{3} \mathrm{~S}$ is decelerated:

- in samples with added $\mathrm{Li}_{2} \mathrm{CO}_{3}$ even after 90 days of hydration;

- in samples with added $\mathrm{KHCO}_{3}$ at $25{ }^{\circ} \mathrm{C}$ even after 90 days of hydration, at $40^{\circ} \mathrm{C}$ in the first stages of the hydration (3, 7 days), after 28 and 90 days the amount of unreacted $\mathrm{C}_{3} \mathrm{~S}$ is smaller than in PC samples;

- in samples with $\mathrm{K}_{2} \mathrm{CO}_{3}$ in the first stages of the hydration ( 3,7 days), after 28 and 90 days the amount of unreacted $\mathrm{C}_{3} \mathrm{~S}$ is smaller than in $\mathrm{PC}$ samples.

The amount of reacted carbonate in cement hydration at a $15 \%$ addition of slightly or moderately soluble carbonates does not exceed 5\% and is not affected by their solubility. At a $15 \%$ addition of the highly soluble carbonate $\mathrm{K}_{2} \mathrm{CO}_{3}$ a higher amount of carbonate is used up during the hydration process and after 90 days it is around $6 \%$. At the addition of the highly soluble carbonate $\mathrm{KHCO}_{3}$ the change in the $\mathrm{pH}$ value also plays a role in addition to the solubility and great amounts of $\mathrm{CaCO}_{3}$ are formed in samples due to the reaction between dissolved $\mathrm{CO}_{2}$ and $\mathrm{CH}$ (after 90 days they exceed 10\%). The rest of the carbonate serves predominantly as an inert filling.

In PC samples as well as samples with differently soluble carbonates the stable hydration products are Mc, $\mathrm{AFt}$ (at the addition of slightly soluble carbonates), $\mathrm{C} \overline{\mathrm{C}}$, $\mathrm{C}-\mathrm{S}-\mathrm{H}$ and $\mathrm{CH}$. While the samples were prepared with $\mathrm{PC}$ which had a molar ratio $\mathrm{SO}_{3} / \mathrm{Al}_{2} \mathrm{O}_{3}=0.9$ and even after 3 days of hydration in all samples Mc and $\mathrm{Hc}$ were not identified, we conclude, that the molar ratio $\mathrm{CO}_{2} / \mathrm{Al}_{2} \mathrm{O}_{3}$ is equal or higher from 1 . That means that all our samples 

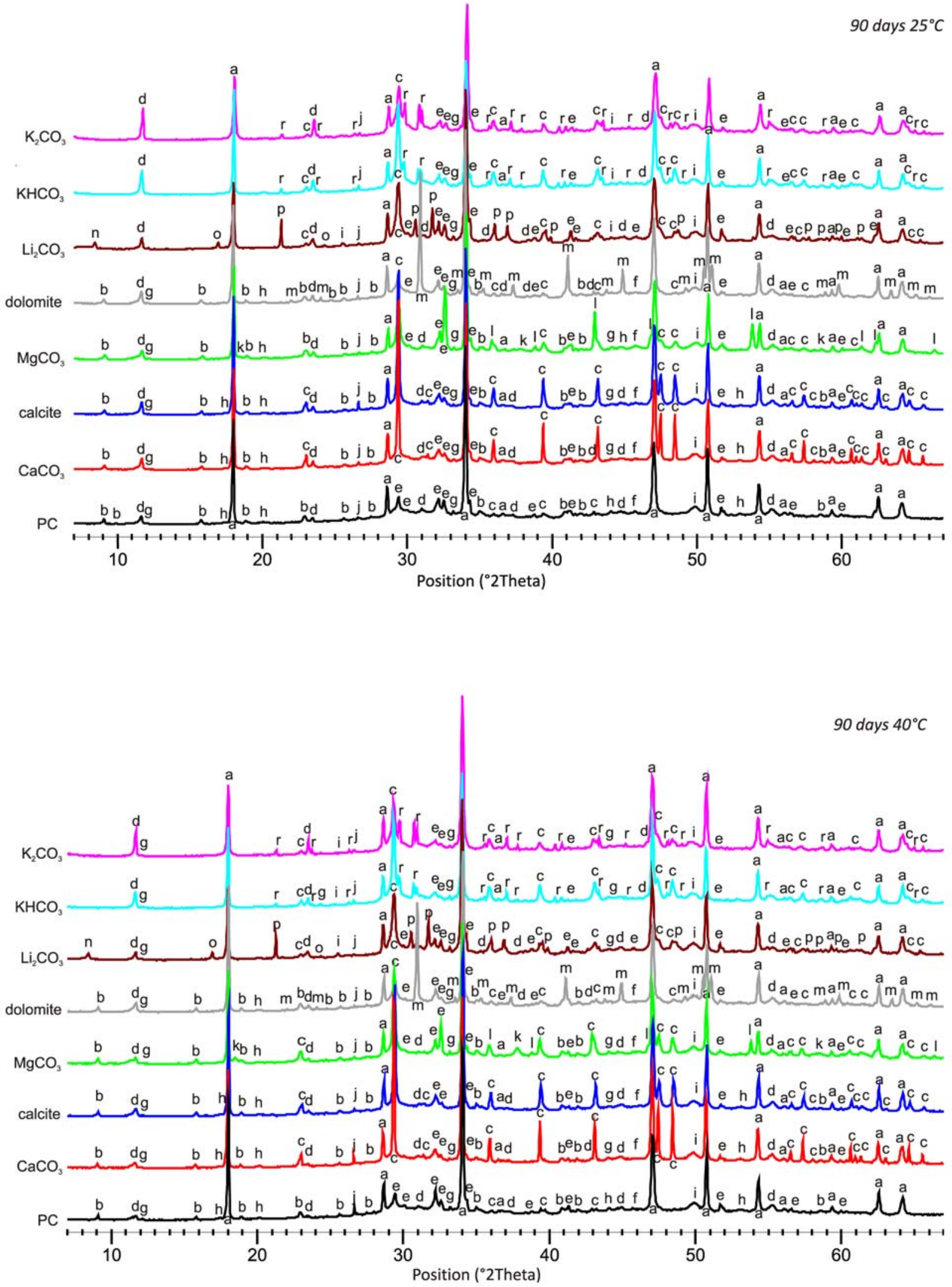

Figure 10. X-ray diffraction patterns of 90 -day hydrated samples at $25{ }^{\circ} \mathrm{C} / 40{ }^{\circ} \mathrm{C}$ and phases identified: a-CH; b-E; c-Calcite; d-Mc; e- $\mathrm{C}_{3} \mathrm{~S}$; f-C $\mathrm{C}_{2} \mathrm{~S}$;

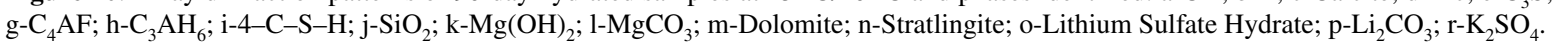


(also include samples of pure PC) had excess of reactive carbonate after 3 days of hydration already.

The amount of Mc after 90 days of hydration at the addition of any kind of carbonates is slightly higher than in PC samples. With the presence of differently soluble carbonates Mc is stabilized and in turn causes AFt to be stabilized in slightly soluble carbonates, whereas the formation of AFt in moderately and highly soluble carbonates is hindered. The amount of AFt in samples with or without the added slightly soluble carbonates is comparable and after $90 \%$ days of hydration the content is around $4 \%$. It is well known that the addition of carbonate affects the change of the $\mathrm{Ca} / \mathrm{Si}$ ratio in $\mathrm{C}-\mathrm{S}-\mathrm{H}$, but it cannot cause the formation of new C-S-H gel, as it has no pozzolanic qualities. Scientific writings show us that a part of the carbonate is incorporated in the $\mathrm{C}-\mathrm{S}-\mathrm{H}$, at which point calcium silicocarbonate hydrates are formed but we could not identify any with Rietveld method. We do, however, predict their formation, as with the addition of slightly soluble carbonates $\left(\mathrm{C} \overline{\mathrm{C}}\right.$, calcite, $\left.\mathrm{MgCO}_{3}\right)$ we can identify comparable $\mathrm{C}-\mathrm{S}-\mathrm{H}$ contents only after 90 days of hydration compared to clear PC samples, even if the hydration of di-/tri- silicates is accelerated. The amount of identified $\mathrm{C}-\mathrm{S}-\mathrm{H}$ increases with the solubility of the added carbonates and after 90 days of hydration with the addition of the slightly soluble carbonate dolomite the $\mathrm{C}-\mathrm{S}-\mathrm{H}$ contents exceed those of PC samples by $1 \%$, with the addition of the medium soluble carbonate $\mathrm{Li}_{2} \mathrm{CO}_{3}$ and the highly soluble carbonate $\mathrm{KHCO}_{3}$ it is even higher for about $2 \%$, with the addition of $\mathrm{K}_{2} \mathrm{CO}_{3}$ the $\mathrm{C}-\mathrm{S}-\mathrm{H}$ contents are higher for about $5 \%$. Even though the quantification of $\mathrm{C}-\mathrm{S}-\mathrm{H}$ with XRD analysis is more difficult and harder to determine due to its semi amorphous nature, we can conclude based on the gathered data that the addition of carbonates affects its formation during the hydration - in the way of changing the $\mathrm{Ca} / \mathrm{Si}$ relation and/or partial inclusion of $\mathrm{CO}_{3}{ }^{2-}$ into its structure.

The crystallinity of the samples does not depend on temperature and after 90 days of hydration is always lower than after 3 days of hydration both in PC samples as well as at the addition of differently soluble carbonates. After 90 days of hydration the crystallinity in PC samples is $31 \%$, after the addition of slightly soluble carbonates the crystallinity is higher for about $10 \%$, after the addition of moderately soluble carbonates for about $18 \%$ and after the addition of highly soluble carbonates for about $14 \%$ (when compared to clear samples of PC).

\section{Conclusions}

We can conclude that blending of PC with differently soluble carbonates was found to influence the hydrate assemblage of the hydrated cement. With the help of the Rietveld analysis the study indicated that Mc and not Ms were stable in the presence of any carbonate. Even more, the Mc was stabilized in the presence of slightly soluble carbonates, consequently causing the stabilization of AFt. The amount of Mc after 90 days of hydration at the addition of any kind of carbonates is slightly higher than in PC. In the presence of either medium or highly soluble carbonates AFt is not formed or its formation is delayed. Their amount is comparable in samples with or without slightly soluble carbonates. Carbonates accelerate the hydration of the clinker phases $\mathrm{C}_{2} \mathrm{~S}$ and $\mathrm{C}_{3} \mathrm{~A}$, whereas the hydration of $\mathrm{C}_{3} \mathrm{~S}$ is accelerated in slightly soluble carbonates and decelerated in moderately and highly soluble carbonates. The amount of reacted carbonate in cement hydration at a $15 \%$ addition of slightly or medium soluble carbonates does not exceed $5 \%$ and is not affected by their solubility; at a $15 \%$ addition of the highly soluble carbonate $\mathrm{K}_{2} \mathrm{CO}_{3}$ it is around $6 \%$. An increase in temperature $(25$ to $40{ }^{\circ} \mathrm{C}$ ) gradually effects one, the rate of hydration and two, the quantity of stable phase assemblage (E in slightly soluble carbonate-blended cements, monocarboaluminate, calcite and portlandite).

The crystallinity of the samples is independent on the temperatures $\left(25\right.$ to $40{ }^{\circ} \mathrm{C}$ ) and is after the 90 days of hydration always lower than after 3 days of hydration in the samples of clear PC and in the samples to which carbonate was added.

\section{References}

1. EN 197-1, European Standard, Cement - Part 1, Composition, specifications and conformity criteria for common cements, CEN, Brussels, 2000.

2. I. Soroka, N. Setter, Cem. Concr. Res. 1977, 7, 449-456. https://doi.org/10.1016/0008-8846(77)90073-4

3. T. Matschei, B. Lothenbach, F. P. Glasser, Cem. Concr. Res. 2007, 37, 551-558.

https://doi.org/10.1016/j.cemconres.2006.10.013

4. T. Matschei, B. Lothenbach, F. P. Glasser, Cem. Concr. Res. 2007, 37, 118-130. https://doi.org/10.1016/j.cemconres.2006.10.010

5. R. D. Hooten, M. Nokken, M. D. A. Thomas, PortlandLimestone Cement: State-of-the-Art Report and Gap Analysis for CSA A 3000, Cement Association of Canada, Toronto, 2007, 59 pp.

6. Vuk, V. Kaučič, J. Maček, A. Meden, J. Am. Ceram. Soc. 2011, 94, 1238-1242.

7. V. S. Ramachandran, Thermochim. Acta 1988, 127, 385-394. https://doi.org/10.1016/0040-6031(88)87515-4

8. V. S. Ramachandran, C. Zhang, Mater. Constr. 1986, 19 , 437-444. https://doi.org/10.1007/BF02472147

9. C. Vernet, G. Noworyta, Proc. Int. Congr. Chem. Cem., 9th, New Delhi, India IV, 1992, pp. 430-436.

10. V. L. Bonavetti, V. F. Rahhal, E. F. Irassar, Cem. Concr. Res. 2001, 31, 853-859.

https://doi.org/10.1016/S0008-8846(01)00491-4

11. B. Lothenbach, G. Le Saout, E. Gallucci, K. Scrivener, Cem. 
Concr. Res. 2008, 38, 848-860.

https://doi.org/10.1016/j.cemconres.2008.01.002

12. J. Pera, S. Husson, B. Guilhot, Cem. Concr. Comp. 1999, 21, 99-105. https://doi.org/10.1016/S0958-9465(98)00020-1

13. K. Sersale, Proc. Int. Congr. Chem. Cem., 9th, New Delhi, India I, 1992, pp. 277-279.

14. S. Husson, B. Guilhot, J. Pera, Proc. Int. Congr. Chem. Cem., 9th, New Delhi, India IV, 1992, pp. 83-89.

15. B. Lothenbach, T. Matschei, G. Moeschner, F. P. Glasser, Cem. Concr. Res. 2008, 38, 1-18.

https://doi.org/10.1016/j.cemconres.2007.08.017

16. T. Matschei, F. P. Glasser, Cem. Concr. Res. 2010, 40, 763-777. https://doi.org/10.1016/j.cemconres.2009.11.010

17. K. L. Scrivener, T. Fuellmann, E. Gallucci, G. Walenta, E. Bermejo, Cem. Concr. Res. 2004, 34, 1541-1547.

https://doi.org/10.1016/j.cemconres.2004.04.014
18. V. S. Ramachandran, J. J. Beaudoin (Ed.): Handbook of analytical techniques in concrete science and technology, Principles, Techniques and Applications, Noyes Publications, Norwich, 2001, pp. 275-333.

19. R. A. Young (Ed.), The Rietveld Method, Oxford Science Publications, Oxford University Press, 1995, 308 pp.

20. D. R. Lide (Ed.), CRC Handbook of Chemistry and Physics, $90^{\text {th }}$ Edition, CD-ROM version 2010.

21. S. Gali, C. Ayora, P. Alfonso, E. Tauler, M. Labrador, Cem. Concr. Res. 2001, 31, 933-939. https://doi.org/10.1016/S0008-8846(01)00499-9

22. P. Gu, J. J. Beaudoin, J. Mater. Sci. Lett. 1997, 16, 696-698. https://doi.org/10.1023/A:1018504324894

\section{Povzetek}

Učinek apnenca na hidratacijo Portland cementa so študirali mnogi raziskovalci, učinek bolj topnih karbonatov pa doslej ni bil pojasnjen. Zato smo izvedli kvalitativno in kvantitativno študijo vpliva slabo topnih $\left(\mathrm{CaCO}_{3}, \mathrm{MgCO}_{3}\right.$, dolomit), srednje topnih $\left(\mathrm{Li}_{2} \mathrm{CO}_{3}\right)$ in dobro topnih $\left(\mathrm{K}_{2} \mathrm{CO}_{3}\right.$ in $\left.\mathrm{KHCO}_{3}\right)$ karbonatov na hidratacijo.

Ugotovili smo, da dodatek različno topnih karbonatov Portland cementu vpliva na fazno sestavo hidratiranega cementa. Rietveldova analiza je pokazala, da pri $15 \%$ dodatku slabo in srednje topnih karbonatov ne reagira več kot $5 \%$ karbonata, medtem ko je pri $15 \%$ dodatku dobro topnega $\mathrm{K}_{2} \mathrm{CO}_{3}$ količina reagiranega karbonata dosegla približno $6 \%$.

Povišana temperatura (s 25 na $40{ }^{\circ} \mathrm{C}$ ) vpliva tako na hitrost hidratacije kot na končno fazno sestavo hidratiranega cementa. 